\title{
Skeletal Muscle Metabolism: Origin or Prognostic Factor for Amyotrophic Lateral Sclerosis (ALS) Development?
}

\author{
Cyril Quessada ${ }^{1, \dagger}$, Alexandra Bouscary ${ }^{1,2,+}$, Frédérique René $^{1}$, Cristiana Valle $^{3} \mathbb{C}$, Alberto Ferri $^{3}$, \\ Shyuan T. Ngo ${ }^{4,5,6}$ and Jean-Philippe Loeffler ${ }^{1, *}$ \\ 1 Mécanismes Centraux et Périphériques de la Neurodégénérescence, INSERM, UMR_S 1118, \\ Centre de Recherche de Biomédecine de Strasbourg (CRBS), Université de Strasbourg, \\ F-67000 Strasbourg, France; cyril.quessada@etu.unistra.fr (C.Q.); alexandra.bouscary@neuro-sys.com (A.B.); \\ frederique.rene@unistra.fr (F.R.) \\ 2 Neuro-Sys SAS, F-13120 Gardanne, France \\ 3 IRCCS Fondazione Santa Lucia, Institute of Translational Pharmacology, CNR, 00133 Roma, Italy; \\ cristiana.valle@cnr.it (C.V.); alberto.ferri@cnr.it (A.F.) \\ 4 Australian Institute for Bioengineering and Nanotechnology, The University of Queensland, \\ Brisbane, QLD 4072, Australia; s.ngo@uq.edu.au \\ 5 Centre for Clinical Research, The University of Queensland, Herston, QLD 4006, Australia \\ 6 Queensland Brain Institute, The University of Queensland, St. Lucia, QLD 4072, Australia \\ * Correspondence: loeffler@unistra.fr; Tel.: +33-368853837 \\ + These authors contributed equally to this work.
}

\section{check for} updates

Citation: Quessada, C.; Bouscary, A.; René, F.; Valle, C.; Ferri, A.; Ngo, S.T.; Loeffler, J.-P. Skeletal Muscle Metabolism: Origin or Prognostic Factor for Amyotrophic Lateral Sclerosis (ALS) Development?. Cells 2021, 10, 1449. https://doi.org/ 10.3390/cells10061449

Academic Editors: Gabriella

Dobrowolny, Bianca Maria

Scicchitano and Giorgio Tasca

Received: 2 May 2021

Accepted: 7 June 2021

Published: 9 June 2021

Publisher's Note: MDPI stays neutral with regard to jurisdictional claims in published maps and institutional affiliations.

Copyright: (c) 2021 by the authors. Licensee MDPI, Basel, Switzerland. This article is an open access article distributed under the terms and conditions of the Creative Commons Attribution (CC BY) license (https:/ / creativecommons.org/licenses/by/ $4.0 /)$.

\begin{abstract}
Amyotrophic lateral sclerosis (ALS) is a fatal neurodegenerative disease characterized by progressive and selective loss of motor neurons, amyotrophy and skeletal muscle paralysis usually leading to death due to respiratory failure. While generally considered an intrinsic motor neuron disease, data obtained in recent years, including our own, suggest that motor neuron protection is not sufficient to counter the disease. The dismantling of the neuromuscular junction is closely linked to chronic energy deficit found throughout the body. Metabolic (hypermetabolism and dyslipidemia) and mitochondrial alterations described in patients and murine models of ALS are associated with the development and progression of disease pathology and they appear long before motor neurons die. It is clear that these metabolic changes participate in the pathology of the disease. In this review, we summarize these changes seen throughout the course of the disease, and the subsequent impact of glucose-fatty acid oxidation imbalance on disease progression. We also highlight studies that show that correcting this loss of metabolic flexibility should now be considered a major goal for the treatment of ALS.
\end{abstract}

Keywords: skeletal muscle; ALS; neuromuscular junction; hypermetabolism; PDK4; metabolic imbalance; trimetazidine

\section{Introduction}

In humans, the muscular system is divided into two distinct categories: smooth and striated muscles. The number, organization, and function of striated muscle require considerable energy consumption when compared to the entire human body. In this review, we first present a summary of amyotrophic lateral sclerosis (ALS). Second, we examine the role of muscle energy metabolism in the pathophysiology of ALS and we further discuss how targeting muscle offers an avenue for treating the disease.

\subsection{Amyotrophic Lateral Sclerosis}

Amyotrophic lateral sclerosis (ALS) is a fatal and incurable neurodegenerative disease. The gradual loss of weight and muscle strength and the onset and progression of muscle paralysis are the main visible presentations of this disease. From a cellular perspective, the loss of cortical motor neurons and spinal and bulbar motor neurons is clearly established [1]. 
ALS typically affects patients between the ages of 50 and 60 and invariably causes death 3 to 5 years after onset [2]. Worldwide, 60,000 people die of ALS each year [3] with an incidence of 1.75 to 3 per 100,000 per year [4]. In France, there are 3 to 4 new cases per year per 100,000 individuals and a prevalence of 6000 [5]. Many genes have been directly linked with the sporadic ( $90 \%$ of cases) and familial forms ( $10 \%$ of cases) of ALS [6]. In the latter, the pattern of inheritance is generally autosomal dominant. Among the main major susceptibility genes, C9ORF72, SOD1, FUS and TARDBP account for $48 \%, 12 \%, 5 \%$ and $5 \%$ in familial forms, respectively [5-11]. Currently, only two FDA-approved treatments are indicated for the treatment of ALS: Rilutek and Edaravone. These molecules increase the life expectancy of some patients by a few months $[12,13]$. The pathogenic mechanisms that are proposed to contribute to the degeneration of motor neurons include excitotoxicity, oxidative stress, protein aggregation, alteration of RNA metabolism and mitochondrial dysfunction [14-20] (Figure 1). Two hypotheses integrating these pathogenic mechanisms leading to ALS are currently proposed: the corticofugal dying-forward hypothesis which describes the progressive descending neurodegeneration, initiated in the motor cortex, spreading to the motor neuron and ultimately affecting the neuromuscular junctions (NMJ) [21-23] and the dying back hypothesis which is initiated at the NMJ with a retrograde progression of degeneration [24]. These two hypotheses are not mutually exclusive and may coexist to initiate ALS. The topic of this review is focused on the dying-back process of the motor neurons initiated at the NMJ and how skeletal muscle can be involved in ALS.

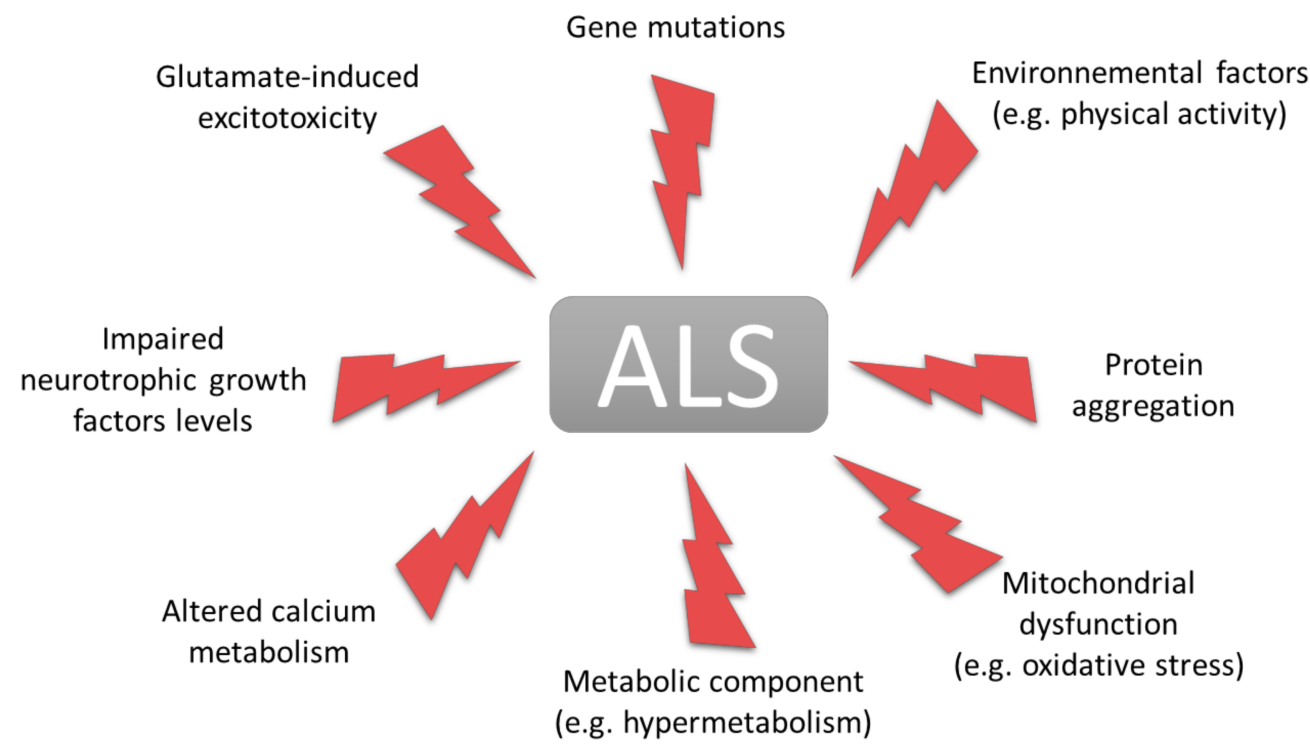

Figure 1. Pathogenic mechanisms thought to contribute to the development of ALS. Current data support several hypotheses that may explain the onset of ALS. Taken individually, these toxic events can mimic some of the hallmarks of ALS. This representation shows the complexity and multifactorial character of this disease.

\subsection{Neuromuscular Junction}

While ALS is clearly a complex disease, skeletal muscle is now being considered a key player in its pathogenesis. Although recent neurophysiological data obtained in ALS patients support an early hyperexcitability of cortical motor neurons, the dismantling of the NMJ is one of the first anatomical pathogenic events in ALS [25]. In both ALS patients and in SOD1 mouse models of ALS [26-30], the dismantling of the NMJ takes place before the degeneration of motor neurons [31-34], when no clinical motor signs are visible [35] (see Table 1). This supports the idea that motor neuron death is not the only cause of NMJ dismantlement but that degeneration begins in the most distal portion of the axon, namely the synapse. In addition, the safeguard of soma does not prevent the loss of NMJs [36,37]. Indeed, the destabilization of NMJs precedes motor neuron death 
and induces the dying-back phenomenon of motor neurons [24]. To clarify the reasons of this dismantling, several studies have been carried out. It was shown that the expression of mutant $S O D 1^{G 93 A}$ and $S O D 1^{G 37 R}$ specifically in muscle led to the loss of NMJ before the loss of motor neuron [38-40]. These data demonstrate that expression of SOD1 mutant limited to skeletal muscle is sufficient by itself to induce NMJ destabilization and may lead to motor neuron death.

Table 1. Summary of the main NMJ alterations found in ALS patients and in ALS mouse models.

- $\quad$ Decrease of motor unit number measured by

Before MUNE in 2 asymptomatic SOD1 mutation carriers out of 19 (no statistics)

Patients

- $33.8 \%$ of NMJ denervated in ALS $(n=10)$ vs. $9.8 \%$ in controls $(n=5) p<0.05$

- P47: Denervation of $40 \%$ of NMJ in medial gastrocnemius ( $n=890)$ (no statistics)

- P80: decrease by $60 \%$ of intact ventral root axons ( $n=4$ /genotype, $n<0.01$ vs. control)

- P58: Denervation of $78 \%$ of type $\mathrm{IIb}$ and $30 \%$ of type IIa fibers in medial gastrocnemius

(2 mice/genotype; 20-30 muscle fibers analyzed; no statistics)

$S O D 1^{G 93 A}$ mice $\quad$ Before

- P48: preferential denervation of type IIb NMJ followed by IIa and I in gastrocnemius ( $n=3$ /genotype; 450 NMJ analyzed; no statistics)

- $\quad$ P30: $40 \%$ denervation of type Ilb NMJ in tibialis anterior $(n=11 /$ genotype; $p \leq 0.05)$

- P30-36: Decrease by $15.5 \%$ of motor unit number measured by Baysian MUNE in gastrocnemius ( $n=10 /$ genotype; $p=0.018$ )

MUNE: motor unit number estimation.

In the skeletal muscle of ALS patients [41,42] and in presymptomatic Sod1 ${ }^{\mathrm{G} 86 \mathrm{R}}$ mice, expression of Nogo-A (neurite outgrowth inhibitor) was significantly increased and was correlated with the severity of disease [43,44]. Nogo-A could therefore participate in the destabilization of the NMJ and therefore in the degeneration of axon terminals of motor neurons. Ablation of Nogo-A in the muscle of Sod1 ${ }^{G 86 R}$ mice was shown to prevent muscle atrophy and denervation and to prolong survival by $10 \%$. Conversely, muscle overexpression of Nogo-A induced muscle atrophy and denervation, and significantly reduced the size of the NMJ [45]. Thus, these data suggest that Nogo-A plays a role in maintaining the integrity and stabilization of neuromuscular synapses in SOD1 ${ }^{\mathrm{G} 93 \mathrm{~A}}$ mice. However, none of these processes would, by itself, be the sole cause of ALS but they could all contribute together to induce ALS. 


\section{Mitochondrial Failure and Oxidative Stress in ALS}

\subsection{Muscle Mitochondria and Respiratory Complexes}

One of the main features of ALS is mitochondrial dysfunction [19,46-50] (Figure 1). Defects in mitochondrial structure [51-53] and function have been observed in the skeletal muscle of sporadic ALS patients $[54,55]$ and animal models of ALS [56,57] (Table 2).

Table 2. Summary of the main mitochondrial changes found in skeletal muscle of ALS patients and ALS mouse models.

- Complex I activity reduced by $40 \%(n=26$ ALS, $n=28$ controls; $p<0.01$ )

- Abnormal morphology (partially swollen, para-crystalline inclusions, vacuoles)

- Mitochondrial aggregates in the sub-sarcolemma zone in 49 out of 49ALS cases

- Ultrastructural abnormalities (giant mitochondria, para-crystalline inclusions) in 5 out of 49 ALS cases

After

- $46 \%$ of patients with cytochrome c oxidase deficiency

- Respiratory chain complex activity decreased by at least $30 \%$ in patients with severe COX deficiency $(8$ out of 50)

- Increase of the maximal oxidative phosphorylation capacity of muscular mitochondria $\left(V_{\max }\right)$ by 1.8 fold ( $n=7$ ALS, $n=7$ controls; $p<0.05)$

- $\quad$ Progressive decrease of complex IV activity as disease progresses ( $n=7$ ALS, $n=7$ controls; $p<0.05$ )

- Complex I activity reduced by $47.5 \%(n=14$ ALS $n=28$ controls; $p<0.01$ )

- Complex I and IV activity reduced by $37.1 \%$ and $43.6 \%$ respectively ( $n=17$ ALS, $n=21$ controls; $p<0.01)$

- P37: Localized loss of inner membrane potential near the NMJ

- $\quad$ Localized increase of calcium release by altered mitochondria after osmotic choc $(n=6 /$ genotype;

$S O D 1^{\text {G93A }}$ mice $\quad$ Before $p<0.0001)$

- P55: Complex I activity reduced by $20 \%$ in the tibialis anterior ( $n=5$ independent experiments, $p<0.0001)$;

- $\quad$ P55: Decrease of oxygen consumption rate (OCR) by $30 \%$ (four independent experiments, with each sample tested in quadruplicate, $p<0.0001$ )

Moreover, early abnormalities in mitochondrial dynamics contribute to the degeneration of motor neurons in culture [61] and may contribute to the pathophysiology of ALS [56]. In addition, mitochondrial calcium overload occurs in the nerve endings of ALS patients [29] and disruption in calcium homeostasis was seen in different cell models expressing mutant SOD1 $[62,63]$, and in the CNS $[62,64]$ and the skeletal muscles of SOD1 ${ }^{\text {G93A }}$ mice [57]. Moreover, in asymptomatic ALS mice, mitochondria of muscle cells are no longer able to regulate calcium signaling around NMJs, and an excessively high concentration of 
calcium in the cytosol may contribute to the progression of muscle atrophy in ALS [57,65]. These data confirm a close link between mitochondrial dysfunction and calcium deregulation, where the latter would consequently cause a defect in the mitochondrial respiratory chain, triggering a vicious cycle.

The main mitochondrial abnormalities found in ALS concern respiratory complexes. Wiedemann and colleagues [58] reported severe deregulation of the respiratory chain complex I, and a decrease in the activity of respiratory complexes I and IV in the muscle of sporadic ALS patients as well as in the muscles of the $S O D 1^{G 93 A}$ mouse model from a presymptomatic stage $[51,54,55,59,66,67]$. Mitochondrial functions also become progressively impaired when disease progresses [55] and abnormalities in mitochondrial DNA result in decreased activity of certain enzymes (e.g., NADH, COX) [59]. In addition, a significant induction of UCP3 protein has been observed in the muscles of ALS patients and ALS mice [68]. UCP3 is an uncoupling protein mainly expressed in the mitochondria of skeletal muscles, and overexpression of UCP3 in this tissue would induce an increase in lipid oxidation ( $\beta$-oxidation) and energy expenditure $[69,70]$. Finally, the overexpression of UCP1 in Sod1 ${ }^{\text {G86R }}$ mice leads to the degeneration of motor neurons, dismantling of the NMJ and decreased survival [71]. Importantly, the alterations observed in skeletal muscle can be detrimental to the integrity of the NMJ [39] without necessarily representing a causal link [72]. Despite data indicating a strong relationship between mitochondrial abnormalities and the progression of ALS, it is still impossible to establish a causal link between these two phenomena [39,71-74].

\subsection{ROS and Oxidative Stress}

Reactive oxygen species (ROS) are very short-lived metabolites produced during oxidative phosphorylation. Under normal physiological conditions, a cell consumes oxygen to produce energy, and at the same time must eliminate the ROS produced via defense mechanisms such as superoxide dismutase (SOD) and antioxidant metalloenzymes [75]. Under conditions of oxidative stress and reduced mitochondrial respiration, large amounts of ROS are produced and lead to cellular damage such as inflammatory response, excitotoxicity, protein aggregation and apoptosis $[76,77]$. Furthermore, increased $\beta$-oxidation of fatty acids leads to the generation of lipid by-products which contribute to lipotoxicity and to ROS production $[78,79]$. Several studies have already demonstrated the implication of oxidative stress in aging and in ALS [14,80,81]. Abnormally high levels of ROS markers were observed in fluids [82,83] and post-mortem tissues from sporadic ALS patients [84-86] (Figure 1). In muscle of Sod1 ${ }^{G 86 R}$ mice, oxidative stress was observed even before the onset of motor symptoms and obvious signs of denervation [87]. Moreover, in muscle of SOD1 ${ }^{G 93 A}$, SOD1 activity was increased throughout ALS progression, indicating the presence of oxidative stress in muscle $[81,88]$. Dobrowolny and colleagues demonstrated that muscle expression of mutant $S O D 1^{G 93 A}$ was sufficient to induce oxidative damage, muscle atrophy and dismantlement of the NMJs [38,73]. Recently, an increased production of ROS was shown in the muscle of $S O D 1^{G 93 A}$ mice and in muscle of wild-type mice with transient overexpression of the $S O D 1^{G 93 A}$ mutation [89]. Changes in mitochondrial functions were dependent on the progression of pathology, and the SOD1 ${ }^{G 93 A}$ mutation was found to directly contribute to mitochondrial dysfunction long before the death of motor neurons. Although the induction of oxidative stress was not sufficient to cause motor neuron death, the above evidence supports the contribution of uncontrolled ROS production in skeletal muscle to ALS development. However, other studies suggest that mitochondrial disorders in ALS are minor [66,90-92] but are increased as ALS escalates [55]. Altogether, these data support the hypothesis of a major involvement of oxidative stress and mitochondrial alterations in ALS progression. 


\section{Metabolic Alterations in Amyotrophic Lateral Sclerosis}

\subsection{Discovery of Hypermetabolism}

Classically presented as a strict disease of the cortical, bulbar and spinal motor neurons, the alterations of skeletal muscle observed in ALS are often considered to reflect the loss of these neurons. However, many studies examining the involvement of altered energy metabolism in ALS are starting to challenge this dogma. One of the major symptoms of ALS is weight loss, which is often studied through the measurement of the body mass index (BMI). As ALS progresses, a reduction in BMI and body fat is reported in patients with ALS [93]. Early insulin resistance [94] and glucose intolerance [95] have also been reported in ALS patients. This insulin resistance, which leads to a decreased sensitivity of the peripheral tissues to insulin and limits nutrients entry into the cells, could participate to the reduced BMI seen in patients. The loss of BMI in ALS is also associated with malnutrition due to dysphagia, and a worse survival outcome [96,97], whereas a high BMI is linked to a lower risk of developing ALS [98,99]. BMI is therefore a prognostic factor for ALS [96,100-103].

In 2001, Desport et al. [104] identified an abnormal increase by $10 \%$ in resting energy expenditure in patients with ALS $(n=62$; sex ratio M/F $=1.07)$ compared to healthy control group $(n=31)$. Defined as hypermetabolism, this phenomenon was subsequently confirmed, in a larger study, and was shown to be significantly increased by $14 \%$ and affected $62.3 \%$ of the 168 ALS patients (sex ratio M/F $=0.97$ ) [105]. Data from the literature report that hypermetabolism affects up to $66 \%$ of ALS patients [104-109] and is an early event that persists throughout the course of disease [108,110,111]. Weight loss [112], hypermetabolism, and dyslipidemia are now considered as three major risk factors for ALS $[107,109,113,114]$, and are associated with the severity of disease [108] (Figure 1). Remarkably, similar to what was seen in ALS patients, Sod1 ${ }^{\mathrm{G} 86 \mathrm{R}}$ and SOD1 ${ }^{\mathrm{G} 93 A}$ mice were hypermetabolic and this metabolic change was already detectable at the clinically asymptomatic stage of the disease [115]. Moreover, an experimental induction of muscle hypermetabolism was sufficient to cause muscle denervation and motor neurons loss [71]. As such, it appears that hypermetabolism negatively impacts the progression of the disease. ALS mice also develop a loss of metabolic flexibility before any motor symptoms. This results in the inability to use glucose for energy production, leading to a decreased glycolysis and an increased $\beta$-oxidation in skeletal muscle [116] (Figure 2).

In addition, this loss of metabolic flexibility preceded hypermetabolism in SOD1 ${ }^{\mathrm{G} 93 \mathrm{~A}}$ mice [60]. Interestingly, both Sod1 ${ }^{\mathrm{G} 86 R}$ [116] and SOD1 ${ }^{\mathrm{G} 93 A}$ [60] mice had marked glucose intolerance from an early stage of ALS, and glucose intolerance is, with dyslipidemia, one of the key features of metabolic dysregulations in ALS patients [117]. One of the major players in this energy imbalance is pyruvate dehydrogenase kinase 4 (PDK4), the major muscle isoform of pyruvate dehydrogenase kinase $[118,119]$, which plays a crucial role in balancing glucose-fatty acid flux. A significant induction of this metabolic marker was found in the skeletal muscles of $\operatorname{Sod} 1^{\mathrm{G} 66 \mathrm{R}}$ and $S O D 1^{G 93 A}$ mice but also in the muscle of ALS patients [116]. The main metabolic changes are summarized below in Table 3.

According to these observations, it can therefore be hypothesized that correcting the energy balance (glucose vs. fatty acid) in skeletal muscle would reduce or slow down the development and/or progression of ALS. 


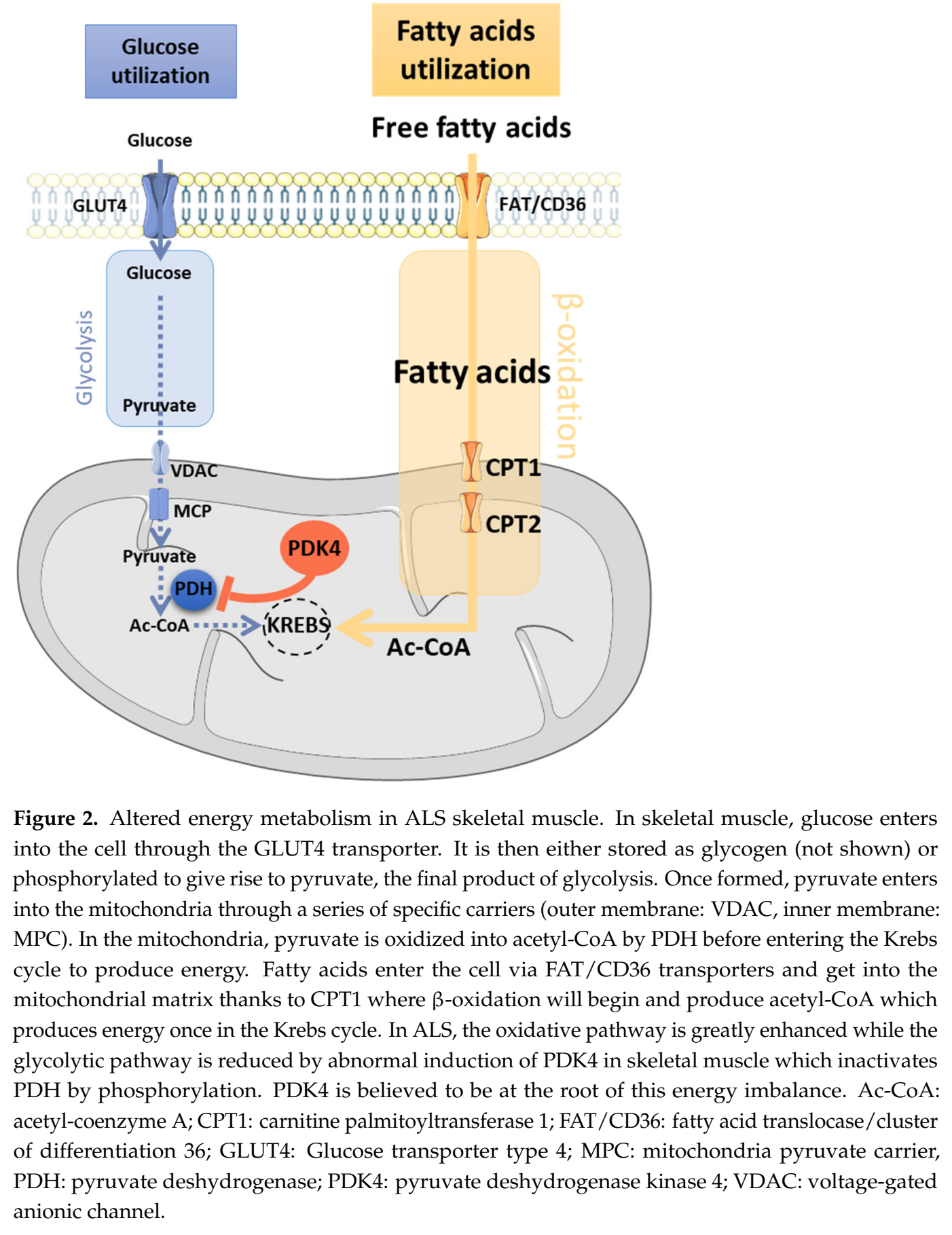


Table 3. Summary of the main alterations of metabolism and contractile properties of skeletal muscle in ALS patients and ALS mouse models. 
Table 3. Cont.

- $\quad$ Swimming straining started at P70 delays disease onset by 2 weeks $(p<0.001)$ and extends survival by 3 weeks $(p<0.01)(n=8 /$ genotype $)$

- $\quad$ P115: the fast-to-slow myofiber transition in the fast-twitch plantaris and TA are significantly limited by the swimming program

- P115: Glut4 and Gapdh mRNA level are reduced by around $75 \%$ in the TA and soleus muscles $(p<0.05)$; Swimming training increases Glut4 and Gapdh mRNA levels to control levels in TA but not in soleus; Pdk4 mRNA level is increased by 2 -fold in TA ( $n=5$ /genotype, $p<0.05)$

$\rightarrow$ Impairment of glycolytic pathway

$\rightarrow$ Physical activity improves metabolism

- $\quad$ P105: Swimming training started at P70 maintains grip strength in ALS mice ( $n=8 /$ genotype, $p<0.05$ vs ALS sedentary mice

- P105: Citrate synthase activity is reduced by $30 \%$ in ALS sedentary mice compared to control $(p=0.0007)$ and swimming training prevents this decrease ( $n=8 /$ condition).

- P105: Malate dehydrogenase activity is increased ed by $25 \%(n=8 /$ condition, $p<0.0001)$

$\rightarrow$ Altered glucose metabolism

$\rightarrow$ Swimming exercise modulates skeletal muscle energy metabolism

- $\quad$ P65: ALS mice have improved performance during endurance exercise

- P65: glucose handling is altered. In TA, glycogen stores are increased, PFK activity is decreased by $23 \%$ (ALS mice $n=7$, control: $n=6 ; p=0 ; 016)$, pyruvate level is 1.7 fold increased ( $n=5$ /genotype; $p=0 ; 019) P d k 4$ mRNA

Before level is 2.2-fold increased in TA compared to control mice (ALS mice $n=8$, control: $n=7 ; p=0 ; 014$ ) while unchanged in soleus.

Sod1 ${ }^{\text {G86R }}$ mice

- $\quad$ Relative mRNA levels of genes involved in lipid handling pathway (Lpl; Cd36; Acsf2; Cpt1; PparB/d) are increased in TA

$\rightarrow$ Metabolic switch: glycolytic pathway is strongly inhibited, and $\beta$-oxidation is enhanced

- P95: grip strength is decreased in ALS mice $(n=8 /$ genotype, $p=0.03$ ) and dichloraoacetate

After treatment prevents grip strength loss (ALS mice: $n=8$; control: $n=9, p=0.0003$ )

DCA corrects the metabolic switch in TA

Acsf2: acyl-CoA synthetase family member 2; Cd36/Fat: fatty acid translocase; Cpt1: carnitine palmitoyltransferase 1; Gapdh: glyceraldehyde3-phosphate dehydrogenase; Glut4: glucose transporter 4; Lpl: lipoprotein lipase; Pdk4: pyruvate dehydrogenase kinase 4; Pfk: phosphofructokinase; $P \operatorname{par} \beta / \delta$ : Peroxisome proliferator-activated receptor $\beta / \delta$; TA: tibialis anterior. 


\subsection{Impairment of Skeletal Muscle Metabolism by Physical Activity}

The muscular system requires a considerable supply of energy to handle a variety of physical challenges. To do this, skeletal muscle adapts its energy needs continuously, according to its environment. The selection of fuel source is based on the interaction between the metabolism of glucose and that of fatty acids and is controlled by the Randle cycle [127]. During short and intense exercise (e.g., sprinting), the involvement of fast-type glycolytic fibers necessitates that glucose oxidation (glycolysis) is favored as the primary fuel pathway. Conversely, during sustained moderate exercise (e.g., a marathon, jogging), which mobilizes slow type oxidative fibers, the oxidation of fatty acids ( $\beta$-oxidation) is preferred [128]. Subjected to different conditions (e.g., intensive and repeated sports activity), muscle fibers adapt and change their phenotypic profile. For example, endurance training is correlated with a strong release of fatty acids and an improved fatty acid muscle absorption [129], thus reflecting improved $\beta$-oxidation and changes in muscle fiber type composition [130]. Intense physical exercise is increasingly studied in ALS due to the large number of patients diagnosed with ALS having had a sustained athletic career (Figure 1). Several studies reported a high risk of ALS for athletes such as soccer players, baseballers or tennis players [131-134]. However, one cannot exclude that other associated factors such as exposure to pesticides, doping agents or repeated injuries could be the cause or could participate in the development of the disease [135-137].

However, this link between high level athletes [133] or people with an intense lifestyle [138,139] and ALS is still debated. Indeed, some studies do not observe any link between physical activity and ALS [140,141] nor report activity as being a risk factor for the disease [142] given that ALS patients who perform moderate exercise in the clinic have improved ALSFRS scores [143]. As such, considering physical activity as a risk factor is highly controversial. Based on published data, it appears that if physical activity is not directly causative of ALS, it might in some cases worsen disease progression. Interestingly, in ALS mice, the type of physical exercise performed appeared to be either deleterious or protective. Indeed, Mahoney and his colleagues showed that high intensity exercise was detrimental to motor performance and survival in male SOD1 ${ }^{\mathrm{G} 93 \mathrm{~A}}$ mice [144]. In contrast, in the same ALS mouse line, high frequency and large amplitude exercise, such as swimming, improved motor functions, delayed the loss of motor neurons, and significantly lengthened survival [125]. In addition, swimming had significant benefits on energy metabolism in the muscle, allowing it to reuse glucose as an energy source at the expense of lipids [120], while improving muscle strength [126]. Moreover, moderate exercise (low-speed treadmill running or free access to running wheel) significantly preserved motor performance as well as motor neuron density [145,146], unlike intense exercise (high-speed treadmill running) which slightly accelerated the onset of motor disorders [145]. The differences in effects between these two types of exercise result from the documented fact that swimming causes fast twitch fiber type transition and lactate production which promotes glucose metabolism [147]. Overall, the beneficial effects of swimming can be explained by the type of fibers recruited during this type of physical exercise. Swimming preferentially solicits fast fibers while endurance exercise recruits slow fibers [147]. These data demonstrate the benefit of preserving and/or stimulating glycolytic metabolism in skeletal muscle which is compromised in ALS.

\subsection{The Metabolic Switch of Muscle Fiber Types in ALS}

In ALS, fast-type synaptic connections are more vulnerable as the disease progresses, while slow-type synapses are relatively spared until the end stage of the disease [31]. In 2007, Hegedus and colleagues proposed that the loss of motor units occurred before the detection of key motor symptoms and loss of motor neurons [122]. In addition, in the $S O D 1^{G 93 A}$ mouse model, they showed that contraction force of the tibialis anterior (TA), a glycolytic muscle, was reduced when compared to the gastrocnemius, an oxidative muscle. This observation was correlated with a selective and progressive degeneration of motor neurons innervating glycolytic fibers twitch (especially IIB fibers) [123]. It is now accepted that there is a change in muscle fiber types from glycolytic to oxidative in muscle of ALS patients [121], of SOD1 ${ }^{G 93 A}$ mice [123-125] and of mice expressing SOD1 
mutant specifically in skeletal muscle $[38,39,73]$. Interestingly, at the onset of the disease, the entry of glucose into muscle fibers was not affected $[115,148]$, suggesting that glucose is rerouted to glycogen stores, rather than being immediately used as a source of energy. Indeed, a decrease in glycogen synthase was observed at the presymptomatic stage of disease in Sod1 ${ }^{G 86 R}$ mice, and this was associated with the deterioration of glycolysis as well as unused glycogen stores in muscle [116]. In $S O D 1^{G 93 A}$, the proportion of glycolytic fibers was reduced when compared to oxidative fibers. This was consistent with the induction of oxidative myosin heavy chains and the repression of glycolytic myosin heavy chains $[60,125]$. Additionally, a muscle transition from a glycolytic to oxidative phenotype was described in Sod1 ${ }^{\text {G86R }}$ mice throughout the development of ALS [116]. In short, these studies demonstrate that metabolic changes in skeletal muscle are a hallmark of ALS, appear before the motor symptoms in mouse models and can have consequences at the NMJ. They further show that altered energy balance plays a role in the progression of ALS.

\subsection{Main Actors of the Randle Cycle}

To best ensure energy homeostasis, the Randle cycle continuously adapts specific fuel usage (glycolysis vs. B-oxidation) to cellular demand by modifying blood glucose and free fatty acid concentrations via their respective GLUT4 and FAT/CD36 transporters (Figure 2). GLUT4 expression is drastically reduced in patients with ALS [149] and SOD ${ }^{G 93 A}$ mice $[60,120]$ while FAT/CD36 is significantly increased in presymptomatic Sod1 ${ }^{\text {G86R }}$ mice [116]. Thus, the supply of glucose to muscle fibers is no longer assured, leading to insulin resistance [150-152] and glucose intolerance [94,95,153,154] in ALS. At the same time, the CPT1 transporter which allows the entry of fatty acids into the mitochondria was also overexpressed in the SOD1 ${ }^{G 93 A}[60]$ and Sod1 ${ }^{\text {G86R }}$ models $[115,116]$. These data are indicative of a disturbance in the assimilation of energy substrates and highlight metabolic imbalance at the level of the muscle.

Once in the cell, glucose enters glycolysis or is stored as glycogen through the action of glycogen synthase. In Sod1 ${ }^{G 86 R}$ mice, at the asymptomatic stage, glycogen synthase activity and glycogen accumulation are significantly increased in skeletal muscle, suggesting that muscle cells are no longer able to use glycogen to produce energy, reflecting a problem with carbohydrate metabolism [116]. Regarding glycolysis, one of the first enzymes to be affected in ALS is phosphofructokinase 1 (PFK1). Indeed, from a presymptomatic stage, the expression of PFK1 and its activity were significantly reduced in the muscle of Sod1 ${ }^{G 86 R}$ mice [116]. The decrease in PFK1 expression in $S o d 1^{G 86 R}$ mice could be a consequence of an increased uptake of fatty acid, enabled by induction of FAT/CD36 and CPT1 transporters, known to strongly inhibit PFK1 [155]. The reduction in PFK1 expression and activity occurs in response to an overexpression of PDK4 and high levels of PDK4 have been observed in the muscle of ALS patients, and in SOD1 ${ }^{G 93 A}$ and Sod1 ${ }^{G 86 R}$ mice even before any detectable sign of denervation $[60,120]$. While suggesting that the overexpression of PDK4 is not specific for mutations in the SOD1 gene, these data highlight that Randle cycle intermediates become altered in response to changes in glucose-fatty acid flux.

The expression of PDK4 depends on several transcription factors including Foxo1, PGC $1 \alpha$ and PPAR $\beta / \delta$. Foxo1 is an ubiquitous transcription factor that was strongly induced in muscles of $S O D 1^{G 93 A}$ and $S o d 1^{G 86 R}$ mice, as well as non-transgenic animals after sciatic nerve injury [116]. PGC1 $\alpha$ plays an essential role in regulating the expression of genes involved in energy metabolism, lipid metabolism and in mitochondrial biogenesis [156-160]. Muscle overexpression of PGC1 $\alpha$ leads to an induction of genes involved in the oxidative pathway, causing repression of glycolytic enzymes and glucose intolerance [161]. In mutant SOD1 ${ }^{G 37 R}$ mice, skeletal muscle induction of PGC1 $\alpha$ led to maintenance of mitochondrial biogenesis, improved muscle function at the latter stages of disease [162], and was associated with an increase in oxidative type IIA fibers [163]. Alternatively, overexpression of $\operatorname{PPAR} \beta / \delta$ in skeletal muscle increased the proportion of type 1 oxidative fibers [164], and constitutive overexpression of PPAR $\beta / \delta$ increases mitochondrial biogenesis and caused a switch from fast to slow fiber type [165]. 
Taken together, these studies demonstrate the crucial role of muscle energy balance in the pathogenesis of ALS, and are in agreement with the idea that correcting for, or preventing the loss of, metabolic flexibility could be a promising therapeutic approach in ALS.

\section{Pharmacological Strategies for Targeting Energetic Imbalance in ALS}

Below, we present a brief overview of two pharmacological modulators of energy balance that were studied for their possible repositioning as ALS treatments and a third one which is currently under investigation.

\subsection{Dichloroacetate (DCA)}

DCA is a drug that restores optimal glucose oxidation while inhibiting the oxidation of fatty acids [166]. DCA inhibits the activity of PDK and thus stimulates the activity of PDH [167] (Figure 3). In 2012, Miquel and colleagues found that DCA improved mitochondrial function in astrocytes expressing the SOD ${ }^{G 93 A}$ mutation, while preventing their toxicity on cultured motor neurons. Additionally, they found that DCA improved muscle strength, preserved the integrity of NMJs, reduced motor neuron loss and prolonged survival in SOD1 ${ }^{G 93 A}$ mice [168]. In addition, DCA also delayed the onset of motor symptoms in Sod1 ${ }^{G 86 R}$ mice by limiting denervation and muscle atrophy [116]. The benefits observed in Sod1 ${ }^{G 86 R}$ mice could be explained by the protective effect of DCA on muscle fibers by restoring the energy balance or preventing its imbalance. Treatment with DCA limited the expression of genes controlling the oxidative pathway (e.g., PDK4, Foxo1 and $\operatorname{PPAR} \beta / \delta$ ) and increased the expression of those involved in the glycolytic pathway (e.g., PFK1). Moreover, DCA treatment improved motor functions, reduced the expression of denervation and atrophy markers, and limited oxidative stress [116]. These data therefore prove that restoring or preserving the metabolic balance can prevent oxidative stress, protect mitochondria, and prevent denervation and muscle atrophy in Sod1 ${ }^{\text {G86R }}$ mice. Although DCA exerts a number of beneficial effects, translation into the clinic is limited as long-term use of DCA leads to hepatotoxicity [169].

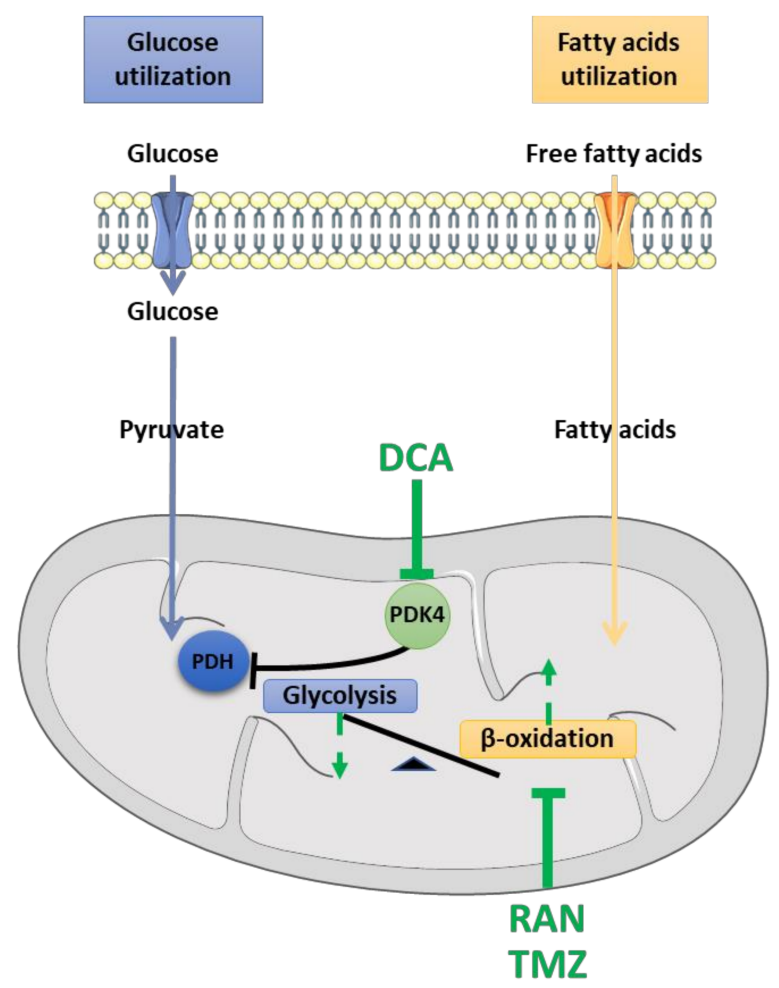

Figure 3. Metabolic reprogramming of skeletal muscle by pharmacological approaches. 
In ALS skeletal muscle, energy metabolism is disturbed: glycolysis is decreased while $\beta$-oxidation is increased. The three presented drugs could help normalize this energy imbalance. DCA can restore glycolysis by inhibiting PDK4 activity. RAN and TMZ inhibit $\beta$-oxidation. A correction of the glucose-fatty acid balance could explain the beneficial effects of these molecules found in various studies on ALS.

\subsection{Ranolazine (RAN)}

RAN is a $\beta$-oxidation inhibitor approved by the FDA for the treatment of angina pectoris [170-173]. RAN increases the oxidation of glucose [174-176] in patients with symptoms of chronic angina pectoris [177] or congenital myotonia [178] (Figure 3). Several studies have shown its efficacy against insulin resistance in animals [179] and patients with type 2 diabetes $[180,181]$. Despite its beneficial effects on energy metabolism, only one group of researchers working on ALS have exploited RAN efficacy. In 2020, RAN was shown to significantly improve motor functions, restore metabolic homeostasis of skeletal muscle, and prevent hypermetabolism in $S O D 1^{G 93 A}$ mice. Due to the extreme severity of ALS, the positive effects of RAN could not be sustained until the final stage of the disease and could not affect the survival of animals [60]. Therefore, the putative utility of RAN remains an open question. Further preclinical studies, followed by clinical trials, are still needed at this stage to clarify whether RAN can be used as a clinically relevant drug to cure ALS.

\subsection{Trimetazidine (TMZ)}

TMZ is an anti-anginal and anti-ischemic agent $[182,183]$ that inhibits the oxidation of fatty acids and promotes the oxidation of glucose $[175,184,185]$. The target of TMZ is the 3-ketoacyl thiolase, an enzyme involved in the last step of $\beta$-oxidation [184] (Figure 3). Recently, Ferraro and colleagues showed improved motor performance in a mouse model of sarcopenia after TMZ treatment [186]. In addition, this molecule increased the differentiation of C2C12 myoblasts and induced myogenesis in a tumor-bearing mouse model [187]. A recent study investigating the effects of TMZ on the peripheral nervous system demonstrated an antioxidant effect of TMZ, which resulted in a microenvironment conducive to nerve regeneration and increased remyelination [188]. Based on its pharmacological properties, TMZ appears as an interesting drug to test on ALS models. In preliminary experiments, TMZ significantly increased the motor functions of Sod1 ${ }^{\mathrm{G} 86 \mathrm{R}}$ mice. We are currently pursuing these experiments to decipher the molecular mechanisms by which TMZ exerts its positive effects on ALS mice.

\section{Open Questions and Future Directions}

From recent works, it is now clear that ALS is not solely a neuronal disease but that the target of motor neurons, namely the skeletal muscle, is also a major player in disease initiation and progression. Further, the type of metabolism (e.g., glycolysis versus $\beta$-oxidation) is also decisive. There is clearly a shift in metabolism from glycolytic toward $\beta$-oxidation when disease progresses. This might account for the increased oxidative stress since, at a given ATP demand, producing the cellular fuel from $\beta$-oxidation consumes more oxygen and subsequently increases ROS production. We saw above that several molecules such as DCA, but also FDA-approved drugs such RAN or TMZ, can be repositioned for treating ALS to restore glycolysis in ALS mouse models and exert positive effects on muscle strength. Future studies should now be aimed at studying the effects of these drugs in ALS patients.

\section{Conclusions}

In conclusion, ALS is a highly complex disease. ALS etiology and the multiple pathophysiological mechanisms that trigger the disease remain poorly understood. However, it is clear that skeletal muscle and its bioenergetic disturbances are involved in the development of the disease. Metabolic alterations observed in skeletal muscle in patients with ALS, 
and in mouse models of the disease prior to motor neuron degeneration, challenge the idea of ALS being a disease that originates from the neuron. Further investigations of muscle energy metabolism are essential and necessary to define new therapeutic approaches and to develop drug candidates for treating ALS.

Funding: Not applicable.

Institutional Review Board Statement: Not applicable.

Informed Consent Statement: Not applicable.

Data Availability Statement: Not applicable.

Conflicts of Interest: The authors declare no conflict of interest.

\section{References}

1. Rowland, L.P.; Shneider, N.A. Amyotrophic Lateral Sclerosis. N. Engl. J. Med. 2001, 13. [CrossRef] [PubMed]

2. van Es, M.A.; Hardiman, O.; Chio, A.; Al-Chalabi, A.; Pasterkamp, R.J.; Veldink, J.H.; van den Berg, L.H. Amyotrophic Lateral Sclerosis. Lancet 2017, 390, 2084-2098. [CrossRef]

3. Petrov, D.; Mansfield, C.; Moussy, A.; Hermine, O. ALS Clinical Trials Review: 20 Years of Failure. Are We Any Closer to Registering a New Treatment? Front. Aging Neurosci. 2017, 9. [CrossRef] [PubMed]

4. Masrori, P.; Van Damme, P. Amyotrophic Lateral Sclerosis: A Clinical Review. Eur. J. Neurol. 2020, 27, 1918-1929. [CrossRef]

5. Couratier, P.; Corcia, P.; Lautrette, G.; Nicol, M.; Preux, P.-M.; Marin, B. Epidemiology of Amyotrophic Lateral Sclerosis: A Review of Literature. Rev. Neurol. 2016, 172, 37-45. [CrossRef]

6. Renton, A.E.; Chiò, A.; Traynor, B.J. State of Play in Amyotrophic Lateral Sclerosis Genetics. Nat. Neurosci. 2014, 17, 17-23. [CrossRef]

7. Renton, A.E.; Majounie, E.; Waite, A.; Simón-Sánchez, J.; Rollinson, S.; Gibbs, J.R.; Schymick, J.C.; Laaksovirta, H.; van Swieten, J.C.; Myllykangas, L.; et al. A Hexanucleotide Repeat Expansion in C9ORF72 Is the Cause of Chromosome 9p21-Linked ALS-FTD. Neuron 2011, 72, 257-268. [CrossRef]

8. Millecamps, S.; Salachas, F.; Cazeneuve, C.; Gordon, P.; Bricka, B.; Camuzat, A.; Guillot-Noel, L.; Russaouen, O.; Bruneteau, G.; Pradat, P.-F.; et al. SOD1, ANG, VAPB, TARDBP, and FUS Mutations in Familial Amyotrophic Lateral Sclerosis: GenotypePhenotype Correlations. J. Med. Genet. 2010, 47, 554-560. [CrossRef]

9. Millecamps, S.; Boillée, S.; Le Ber, I.; Seilhean, D.; Teyssou, E.; Giraudeau, M.; Moigneu, C.; Vandenberghe, N.; Danel-Brunaud, V.; Corcia, P.; et al. Phenotype Difference between ALS Patients with Expanded Repeats in C9ORF72 and Patients with Mutations in Other ALS-Related Genes. J. Med. Genet. 2012, 49, 258-263. [CrossRef]

10. Kwiatkowski, T.J.; Bosco, D.A.; LeClerc, A.L.; Tamrazian, E.; Vanderburg, C.R.; Russ, C.; Davis, A.; Gilchrist, J.; Kasarskis, E.J.; Munsat, T.; et al. Mutations in the FUS/TLS Gene on Chromosome 16 Cause Familial Amyotrophic Lateral Sclerosis. Science 2009, 323, 1205-1208. [CrossRef]

11. Vance, C.; Rogelj, B.; Hortobagyi, T.; De Vos, K.J.; Nishimura, A.L.; Sreedharan, J.; Hu, X.; Smith, B.; Ruddy, D.; Wright, P.; et al. Mutations in FUS, an RNA Processing Protein, Cause Familial Amyotrophic Lateral Sclerosis Type 6. Science 2009, 323, $1208-1211$. [CrossRef]

12. Abe, K. Safety and Efficacy of Edaravone in Well Defined Patients with Amyotrophic Lateral Sclerosis: A Randomised, DoubleBlind, Placebo-Controlled Trial. Lancet Neurol. 2017, 16, 8. [CrossRef]

13. Dorst, J.; Ludolph, A.C.; Huebers, A. Disease-Modifying and Symptomatic Treatment of Amyotrophic Lateral Sclerosis. Adv. Neurol. Disord. 2018, 11, 1756285617734734. [CrossRef]

14. Barber, S.C.; Shaw, P.J. Oxidative Stress in ALS: Key Role in Motor Neuron Injury and Therapeutic Target. Free Radic. Biol. Med. 2010, 48, 629-641. [CrossRef]

15. Fischer-Hayes, L.R.; Brotherton, T.; Glass, J.D. Axonal Degeneration in the Peripheral Nervous System: Implications for the Pathogenesis of Amyotrophic Lateral Sclerosis. Exp. Neurol. 2013, 246, 6-13. [CrossRef]

16. Ling, S.-C.; Polymenidou, M.; Cleveland, D.W. Converging Mechanisms in ALS and FTD: Disrupted RNA and Protein Homeostasis. Neuron 2013, 79, 416-438. [CrossRef]

17. Blokhuis, A.M.; Groen, E.J.N.; Koppers, M.; van den Berg, L.H.; Pasterkamp, R.J. Protein Aggregation in Amyotrophic Lateral Sclerosis. Acta. Neuropathol. 2013, 125, 777-794. [CrossRef]

18. Bogaert, E.; d'Ydewalle, C.; Van Den Bosch, L. Amyotrophic Lateral Sclerosis and Excitotoxicity: From Pathological Mechanism to Therapeutic Target. CNSNDDT 2010, 9, 297-304. [CrossRef]

19. Cozzolino, M.; Carrì, M.T. Mitochondrial Dysfunction in ALS. Prog. Neurobiol. 2012, 97, 54-66. [CrossRef]

20. Mejzini, R.; Flynn, L.L.; Pitout, I.L.; Fletcher, S.; Wilton, S.D.; Akkari, P.A. ALS Genetics, Mechanisms, and Therapeutics: Where Are We Now? Front. Neurosci. 2019, 13, 1310. [CrossRef]

21. Eisen, A.; Kim, S.; Pant, B. Amyotrophic Lateral Sclerosis (ALS): A Phylogenetic Disease of the Corticomotoneuron? Muscle Nerve 1992, 15, 219-224. [CrossRef] 
22. Eisen, A.; Braak, H.; Del Tredici, K.; Lemon, R.; Ludolph, A.C.; Kiernan, M.C. Cortical Influences Drive Amyotrophic Lateral Sclerosis. J. Neurol. Neurosurg. Psychiatry 2017, 88, 917-924. [CrossRef] [PubMed]

23. Brunet, A.; Stuart-Lopez, G.; Burg, T.; Scekic-Zahirovic, J.; Rouaux, C. Cortical Circuit Dysfunction as a Potential Driver of Amyotrophic Lateral Sclerosis. Front. Neurosci. 2020, 14, 363. [CrossRef] [PubMed]

24. Dadon-Nachum, M.; Melamed, E.; Offen, D. The "Dying-Back" Phenomenon of Motor Neurons in ALS. J. Mol. Neurosci. 2011, 43, 470-477. [CrossRef] [PubMed]

25. Moloney, E.B.; de Winter, F.; Verhaagen, J. ALS as a Distal Axonopathy: Molecular Mechanisms Affecting Neuromuscular Junction Stability in the Presymptomatic Stages of the Disease. Front. Neurosci. 2014, 8. [CrossRef]

26. Fischer, L.R.; Culver, D.G.; Tennant, P.; Davis, A.A.; Wang, M.; Castellano-Sanchez, A.; Khan, J.; Polak, M.A.; Glass, J.D. Amyotrophic Lateral Sclerosis Is a Distal Axonopathy: Evidence in Mice and Man. Exp. Neurol. 2004, 185, 232-240. [CrossRef]

27. Gonzalez de Aguilar, J.-L.; Niederhauser-Wiederkehr, C.; Halter, B.; De Tapia, M.; Di Scala, F.; Demougin, P.; Dupuis, L.; Primig, M.; Meininger, V.; Loeffler, J.-P. Gene Profiling of Skeletal Muscle in an Amyotrophic Lateral Sclerosis Mouse Model. Physiol. Genom. 2008, 32, 207-218. [CrossRef]

28. Tsujihata, M.; Hazama, R.; Yoshimura, T.; Satoh, A.; Mori, M.; Nagataki, S. The Motor End-Plate Fine Structure and Ultrastructural Localization of Acetylcholine Receptors in Amyotrophic Lateral Sclerosis. Muscle Nerve. 1984, 7, 243-249. [CrossRef]

29. Siklós, L.; Engelhardt, J.; Harati, Y.; Smith, R.G.; Joó, F.; Appel, S.H. Ultrastructural Evidence for Altered Calcium in Motor Nerve Terminals in Amyotrophc Lateral Sclerosis: Calcium in ALS Motor Nerve Terminals. Ann. Neurol. 1996, 39, 203-216. [CrossRef]

30. Aggarwal, A. Detection of Preclinical Motor Neurone Loss in SOD1 Mutation Carriers Using Motor Unit Number Estimation. J. Neurol. Neurosurg. Psychiatry 2002, 73, 199-201. [CrossRef]

31. Frey, D.; Schneider, C.; Xu, L.; Borg, J.; Spooren, W.; Caroni, P. Early and Selective Loss of Neuromuscular Synapse Subtypes with Low Sprouting Competence in Motoneuron Diseases. J. Neurosci. 2000, 20, 2534-2542. [CrossRef]

32. Pun, S.; Santos, A.F.; Saxena, S.; Xu, L.; Caroni, P. Selective Vulnerability and Pruning of Phasic Motoneuron Axons in Motoneuron Disease Alleviated by CNTF. Nat. Neurosci. 2006, 9, 408-419. [CrossRef]

33. Vinsant, S.; Mansfield, C.; Jimenez-Moreno, R.; Moore, V.D.G.; Yoshikawa, M.; Hampton, T.G.; Prevette, D.; Caress, J.; Oppenheim, R.W.; Milligan, C. Characterization of Early Pathogenesis in the SOD1 G93A Mouse Model of ALS: Part II, Results and Discussion. Brain Behav. 2013, 3, 431-457. [CrossRef]

34. Ngo, S.T.; Baumann, F.; Ridall, P.G.; Pettitt, A.N.; Henderson, R.D.; Bellingham, M.C.; McCombe, P.A. The Relationship between Bayesian Motor Unit Number Estimation and Histological Measurements of Motor Neurons in Wild-Type and SOD1G93A Mice. Clin. Neurophysiol. 2012, 123, 2080-2091. [CrossRef]

35. Rocha, M.C.; Pousinha, P.A.; Correia, A.M.; Sebastião, A.M.; Ribeiro, J.A. Early Changes of Neuromuscular Transmission in the SOD1(G93A) Mice Model of ALS Start Long before Motor Symptoms Onset. PLoS ONE 2013, 8, e73846. [CrossRef]

36. Gould, T.W.; Buss, R.R.; Vinsant, S.; Prevette, D.; Sun, W.; Knudson, C.M.; Milligan, C.E.; Oppenheim, R.W. Complete Dissociation of Motor Neuron Death from Motor Dysfunction by Bax Deletion in a Mouse Model of ALS. J. Neurosci. 2006, 26, 8774-8786. [CrossRef]

37. Rouaux, C.; Panteleeva, I.; Rene, F.; Gonzalez de Aguilar, J.-L.; Echaniz-Laguna, A.; Dupuis, L.; Menger, Y.; Boutillier, A.-L.; Loeffler, J.-P. Sodium Valproate Exerts Neuroprotective Effects In Vivo through CREB-Binding Protein-Dependent Mechanisms But Does Not Improve Survival in an Amyotrophic Lateral Sclerosis Mouse Model. J. Neurosci. 2007, 27, 5535-5545. [CrossRef]

38. Dobrowolny, G.; Lepore, E.; Martini, M.; Barberi, L.; Nunn, A.; Scicchitano, B.M.; Musarò, A. Metabolic Changes Associated with Muscle Expression of SOD1G93A. Front. Physiol. 2018, 9, 831. [CrossRef]

39. Wong, M.; Martin, L.J. Skeletal Muscle-Restricted Expression of Human SOD1 Causes Motor Neuron Degeneration in Transgenic Mice. Hum. Mol. Genet. 2010, 19, 2284-2302. [CrossRef]

40. Martin, L.J.; Wong, M. Skeletal Muscle-Restricted Expression of Human SOD1 in Transgenic Mice Causes a Fatal ALS-Like Syndrome. Front. Neurol. 2020, 11. [CrossRef]

41. Pradat, P.-F.; Dubourg, O.; de Tapia, M.; di Scala, F.; Dupuis, L.; Lenglet, T.; Bruneteau, G.; Salachas, F.; Lacomblez, L.; Corvol, J.-C.; et al. Muscle Gene Expression Is a Marker of Amyotrophic Lateral Sclerosis Severity. Neurodegener. Dis. 2012, 9, 38-52. [CrossRef] [PubMed]

42. Pradat, P.-F.; Bruneteau, G.; Gonzalez de Aguilar, J.-L.; Dupuis, L.; Jokic, N.; Salachas, F.; Le Forestier, N.; Echaniz-Laguna, A.; Dubourg, O.; Hauw, J.-J.; et al. Muscle Nogo-a Expression Is a Prognostic Marker in Lower Motor Neuron Syndromes. Ann. Neurol. 2007, 62, 15-20. [CrossRef] [PubMed]

43. Jokic, N.; Gonzalez de Aguilar, J.-L.; Pradat, P.-F.; Dupuis, L.; Echaniz-Laguna, A.; Muller, A.; Dubourg, O.; Seilhean, D.; Hauw, J.-J.; Loeffler, J.-P.; et al. Nogo Expression in Muscle Correlates with Amyotrophic Lateral Sclerosis Severity. Ann. Neurol. 2005, 57, 553-556. [CrossRef] [PubMed]

44. Dupuis, L.; Gonzalez de Aguilar, J.-L.; di Scala, F.; Rene, F.; de Tapia, M.; Pradat, P.-F.; Lacomblez, L.; Seihlan, D.; Prinjha, R.; Walsh, F.S.; et al. Nogo Provides a Molecular Marker for Diagnosis of Amyotrophic Lateral Sclerosis. Neurobiol. Dis. 2002, 10, 358-365. [CrossRef]

45. Jokic, N.; Gonzalez de Aguilar, J.; Dimou, L.; Lin, S.; Fergani, A.; Ruegg, M.A.; Schwab, M.E.; Dupuis, L.; Loeffler, J. The Neurite Outgrowth Inhibitor Nogo-A Promotes Denervation in an Amyotrophic Lateral Sclerosis Model. Embo. Rep. 2006, 7, $1162-1167$. [CrossRef] 
46. Bowling, A.C.; Schulz, J.B.; Brown, R.H.; Beal, M.F. Superoxide Dismutase Activity, Oxidative Damage, and Mitochondrial Energy Metabolism in Familial and Sporadic Amyotrophic Lateral Sclerosis. J. Neurochem. 1993, 61, 2322-2325. [CrossRef]

47. Dupuis, L.; Gonzalez de Aguilar, J.-L.; Oudart, H.; de Tapia, M.; Barbeito, L.; Loeffler, J.-P. Mitochondria in Amyotrophic Lateral Sclerosis: A Trigger and a Target. Neurodegener. Dis. 2004, 1, 245-254. [CrossRef]

48. Sasaki, S.; Horie, Y.; Iwata, M. Mitochondrial Alterations in Dorsal Root Ganglion Cells in Sporadic Amyotrophic Lateral Sclerosis. Acta Neuropathol. 2007, 114, 633-639. [CrossRef]

49. Vandoorne, T.; De Bock, K.; Van Den Bosch, L. Energy Metabolism in ALS: An Underappreciated Opportunity? Acta. Neuropathol. 2018, 135, 489-509. [CrossRef]

50. Carrì, M.T.; D’Ambrosi, N.; Cozzolino, M. Pathways to Mitochondrial Dysfunction in ALS Pathogenesis. Biochem. Biophys. Res. Commun. 2017, 483, 1187-1193. [CrossRef]

51. Vielhaber, S.; Winkler, K.; Kirches, E.; Kunz, D.; Büchner, M.; Feistner, H.; Elger, C.E.; Ludolph, A.C.; Riepe, M.W.; Kunz, W.S. Visualization of Defective Mitochondrial Function in Skeletal Muscle Fibers of Patients with Sporadic Amyotrophic Lateral Sclerosis. J. Neurol. Sci. 1999, 169, 133-139. [CrossRef]

52. Chung, M.J.; Suh, Y.-L. Ultrastructural Changes of Mitochondria in the Skeletal Muscle of Patients with Amyotrophic Lateral Sclerosis. Ultrastruct. Pathol. 2002, 26, 3-7. [CrossRef]

53. Menzies, F.M. Mitochondrial Dysfunction in a Cell Culture Model of Familial Amyotrophic Lateral Sclerosis. Brain 2002, 125, 1522-1533. [CrossRef]

54. Crugnola, V.; Lamperti, C.; Lucchini, V.; Ronchi, D.; Peverelli, L.; Prelle, A.; Sciacco, M.; Bordoni, A.; Fassone, E.; Fortunato, F.; et al. Mitochondrial Respiratory Chain Dysfunction in Muscle from Patients with Amyotrophic Lateral Sclerosis. Arch. Neurol. 2010, 67, 6. [CrossRef]

55. Echaniz-Laguna, A.; Zoll, J.; Ponsot, E.; N'Guessan, B.; Tranchant, C.; Loeffler, J.-P.; Lampert, E. Muscular Mitochondrial Function in Amyotrophic Lateral Sclerosis Is Progressively Altered as the Disease Develops: A Temporal Study in Man. Exp. Neurol. 2006, 198, 25-30. [CrossRef]

56. Luo, G.; Yi, J.; Ma, C.; Xiao, Y.; Yi, F.; Yu, T.; Zhou, J. Defective Mitochondrial Dynamics Is an Early Event in Skeletal Muscle of an Amyotrophic Lateral Sclerosis Mouse Model. PLoS ONE 2013, 8, e82112. [CrossRef]

57. Zhou, J.; Yi, J.; Fu, R.; Liu, E.; Siddique, T.; Ríos, E.; Deng, H.-X. Hyperactive Intracellular Calcium Signaling Associated with Localized Mitochondrial Defects in Skeletal Muscle of an Animal Model of Amyotrophic Lateral Sclerosis*. J. Biol. Chem. 2010, 285, 705-712. [CrossRef]

58. Wiedemann, F.R.; Winkler, K.; Kuznetsov, A.V.; Bartels, C.; Vielhaber, S.; Feistner, H.; Kunz, W.S. Impairment of Mitochondrial Function in Skeletal Muscle of Patients with Amyotrophic Lateral Sclerosis. J. Neurol. Sci. 1998, 156, 65-72. [CrossRef]

59. Vielhaber, S. Mitochondrial DNA Abnormalities in Skeletal Muscle of Patients with Sporadic Amyotrophic Lateral Sclerosis. Brain 2000, 123, 1339-1348. [CrossRef]

60. Scaricamazza, S.; Salvatori, I.; Giacovazzo, G.; Loeffler, J.P.; Renè, F.; Rosina, M.; Quessada, C.; Proietti, D.; Heil, C.; Rossi, S.; et al. Skeletal-Muscle Metabolic Reprogramming in ALS-SOD1G93A Mice Predates Disease Onset and Is A Promising Therapeutic Target. iScience 2020, 23, 101087. [CrossRef]

61. Magrané, J.; Manfredi, G. Mitochondrial Function, Morphology, and Axonal Transport in Amyotrophic Lateral Sclerosis. Antioxid. Redox Signal. 2009, 11, 1615-1626. [CrossRef] [PubMed]

62. Jaiswal, M.; Zech, W.-D.; Goos, M.; Leutbecher, C.; Ferri, A.; Zippelius, A.; Carrì, M.; Nau, R.; Keller, B.U. Impairment of Mitochondrial Calcium Handling in a MtSOD1 Cell Culture Model of Motoneuron Disease. BMC Neurosci. 2009, 10, 64. [CrossRef] [PubMed]

63. Carrì, M.T. Expression of a Cu, Zn Superoxide Dismutase Typical of Familial Amyotrophic Lateral Sclerosis Induces Mitochondrial Alteration and Increase of Cytosolic Ca ${ }^{2+}$ Concentration in Transfected Neuroblastoma SH-SY5Y Cells. FEBS Lett. 1997, 414, 365-368. [CrossRef] [PubMed]

64. Damiano, M.; Starkov, A.A.; Petri, S.; Kipiani, K.; Kiaei, M.; Mattiazzi, M.; Flint Beal, M.; Manfredi, G. Neural Mitochondrial $\mathrm{Ca}^{2+}$ Capacity Impairment Precedes the Onset of Motor Symptoms in G93A Cu/Zn-Superoxide Dismutase Mutant Mice: Mitochondrial Ca ${ }^{2+}$ Capacity in Mutant SOD1 Mice. J. Neurochem. 2006, 96, 1349-1361. [CrossRef]

65. Rossi, A.E.; Boncompagni, S.; Dirksen, R.T. Sarcoplasmic Reticulum-Mitochondrial Symbiosis: Bidirectional Signaling in Skeletal Muscle. Exerc. Sport Sci. Rev. 2009, 37, 29-35. [CrossRef]

66. Al-Sarraj, S.; King, A.; Cleveland, M.; Pradat, P.-F.; Corse, A.; Rothstein, J.D.; Leigh, P.N.; Abila, B.; Bates, S.; Wurthner, J.; et al. Mitochondrial Abnormalities and Low Grade Inflammation Are Present in the Skeletal Muscle of a Minority of Patients with Amyotrophic Lateral Sclerosis; an Observational Myopathology Study. Acta Neuropathol. Commun. 2014, 2, 165. [CrossRef]

67. Capitanio, D.; Vasso, M.; Ratti, A.; Grignaschi, G.; Volta, M.; Moriggi, M.; Daleno, C.; Bendotti, C.; Silani, V.; Gelfi, C. Molecular Signatures of Amyotrophic Lateral Sclerosis Disease Progression in Hind and Forelimb Muscles of an SOD1 G93A Mouse Model. Antioxid. Redox Signal. 2012, 17, 1333-1350. [CrossRef]

68. Dupuis, L.; Scala, F.; Rene, F.; Tapia, M.; Oudart, H.; Pradat, P.-F.; Meininger, V.; Loeffler, J.-P. Up-regulation of Mitochondrial Uncoupling Protein 3 Reveals an Early Muscular Metabolic Defect in Amyotrophic Lateral Sclerosis. FASEB J. 2003, 17, 1-19. [CrossRef]

69. Nabben, M.; Hoeks, J. Mitochondrial Uncoupling Protein 3 and Its Role in Cardiac- and Skeletal Muscle Metabolism. Physiol. Behav. 2008, 94, 259-269. [CrossRef] 
70. Aguer, C.; Fiehn, O.; Seifert, E.L.; Bézaire, V.; Meissen, J.K.; Daniels, A.; Scott, K.; Renaud, J.; Padilla, M.; Bickel, D.R.; et al. Muscle Uncoupling Protein 3 Overexpression Mimics Endurance Training and Reduces Circulating Biomarkers of Incomplete B-oxidation. FASEB J. 2013, 27, 4213-4225. [CrossRef]

71. Dupuis, L.; Gonzalez de Aguilar, J.-L.; Echaniz-Laguna, A.; Eschbach, J.; Rene, F.; Oudart, H.; Halter, B.; Huze, C.; Schaeffer, L.; Bouillaud, F.; et al. Muscle Mitochondrial Uncoupling Dismantles Neuromuscular Junction and Triggers Distal Degeneration of Motor Neurons. PLoS ONE 2009, 4, e5390. [CrossRef]

72. Loeffler, J.; Picchiarelli, G.; Dupuis, L.; Gonzalez De Aguilar, J. The Role of Skeletal Muscle in Amyotrophic Lateral Sclerosis. Brain Pathol. 2016, 26, 227-236. [CrossRef]

73. Dobrowolny, G.; Aucello, M.; Rizzuto, E.; Beccafico, S.; Mammucari, C.; Bonconpagni, S.; Belia, S.; Wannenes, F.; Nicoletti, C.; Del Prete, Z.; et al. Skeletal Muscle Is a Primary Target of SOD1G93A-Mediated Toxicity. Cell Metab. 2008, 8, 425-436. [CrossRef]

74. Ioannides, Z.A.; Ngo, S.T.; Henderson, R.D.; McCombe, P.A.; Steyn, F.J. Altered Metabolic Homeostasis in Amyotrophic Lateral Sclerosis: Mechanisms of Energy Imbalance and Contribution to Disease Progression. Neurodegener. Dis. 2016, 16, 382-397. [CrossRef]

75. Smith, E.F.; Shaw, P.J.; De Vos, K.J. The Role of Mitochondria in Amyotrophic Lateral Sclerosis. Neurosci. Lett. 2019, 710, 132933. [CrossRef]

76. Kim, G.H.; Kim, J.E.; Rhie, S.J.; Yoon, S. The Role of Oxidative Stress in Neurodegenerative Diseases. Exp. Neurobiol. 2015, 24, 325-340. [CrossRef]

77. Gandhi, S.; Abramov, A.Y. Mechanism of Oxidative Stress in Neurodegeneration. Oxidative Med. Cell. Longev. 2012, $2012,1-11$. [CrossRef]

78. Zhang, L.; Keung, W.; Samokhvalov, V.; Wang, W.; Lopaschuk, G.D. Role of Fatty Acid Uptake and Fatty Acid $\beta$-Oxidation in Mediating Insulin Resistance in Heart and Skeletal Muscle. Biochim. Et Biophys. Acta (BBA)-Mol. Cell Biol. Lipids 2010, 1801, 1-22. [CrossRef]

79. Aon, M.A.; Bhatt, N.; Cortassa, S.C. Mitochondrial and Cellular Mechanisms for Managing Lipid Excess. Front. Physiol. 2014, 5. [CrossRef]

80. Barber, S.C.; Mead, R.J.; Shaw, P.J. Oxidative Stress in ALS: A Mechanism of Neurodegeneration and a Therapeutic Target. Biochim. Biophys. Acta (BBA)-Mol. Basis Dis. 2006, 1762, 1051-1067. [CrossRef]

81. Mahoney, D.J.; Kaczor, J.J.; Bourgeois, J.; Yasuda, N.; Tarnopolsky, M.A. Oxidative Stress and Antioxidant Enzyme Upregulation in SOD1-G93A Mouse Skeletal Muscle. Muscle Nerve. 2006, 33, 809-816. [CrossRef] [PubMed]

82. Smith, R.G.; Henry, Y.K.; Mattson, M.P.; Appel, S.H. Presence of 4-Hydroxynonenal in Cerebrospinal Fluid of Patients with Sporadic Amyotrophic Lateral Sclerosis. Ann. Neurol. 1998, 44, 696-699. [CrossRef] [PubMed]

83. Mitsumoto, H.; Santella, R.M.; Liu, X.; Bogdanov, M.; Zipprich, J.; Wu, H.-C.; Mahata, J.; Kilty, M.; Bednarz, K.; Bell, D.; et al. Oxidative Stress Biomarkers in Sporadic ALS. Amyotroph. Lateral Scler. 2008, 9, 177-183. [CrossRef] [PubMed]

84. Shaw, P.J.; Ince, P.G.; Falkous, G.; Mantle, D. Oxidative Damage to Protein in Sporadic Motor Neuron Disease Spinal Cord. Ann. Neurol. 1995, 38, 691-695. [CrossRef] [PubMed]

85. Shibata, N.; Nagai, R.; Uchida, K.; Horiuchi, S.; Yamada, S.; Hirano, A.; Kawaguchi, M.; Yamamoto, T.; Sasaki, S.; Kobayashi, M. Morphological Evidence for Lipid Peroxidation and Protein Glycoxidation in Spinal Cords from Sporadic Amyotrophic Lateral Sclerosis Patients. Brain Res. 2001, 917, 97-104. [CrossRef]

86. Chang, Y.; Kong, Q.; Shan, X.; Tian, G.; Ilieva, H.; Cleveland, D.W.; Rothstein, J.D.; Borchelt, D.R.; Wong, P.C.; Lin, C.G. Messenger RNA Oxidation Occurs Early in Disease Pathogenesis and Promotes Motor Neuron Degeneration in ALS. PLoS ONE 2008, 3, e2849. [CrossRef] [PubMed]

87. Halter, B.; Gonzalez de Aguilar, J.-L.; Rene, F.; Petri, S.; Fricker, B.; Echaniz-Laguna, A.; Dupuis, L.; Larmet, Y.; Loeffler, J.-P. Oxidative Stress in Skeletal Muscle Stimulates Early Expression of Rad in a Mouse Model of Amyotrophic Lateral Sclerosis. Free Radic. Biol. Med. 2010, 48, 915-923. [CrossRef]

88. Leclerc, N.; Ribera, F.; Zoll, J.; Warter, J.-M.; Poindron, P.; Lampert, E.; Borg, J. Selective Changes in Mitochondria Respiratory Properties in Oxidative or Glycolytic Muscle Fibers Isolated from G93AhumanSOD1 Transgenic Mice. Neuromuscul. Disord. 2001, 11, 722-727. [CrossRef]

89. Xiao, Y.; Karam, C.; Yi, J.; Zhang, L.; Li, X.; Yoon, D.; Wang, H.; Dhakal, K.; Ramlow, P.; Yu, T.; et al. ROS-Related Mitochondrial Dysfunction in Skeletal Muscle of an ALS Mouse Model during the Disease Progression. Pharmacol. Res. 2018, 138, 25-36. [CrossRef]

90. Echaniz-Laguna, A.; Zoll, J.; Ribera, F.; Tranchant, C.; Warter, J.-M.; Lonsdorfer, J.; Lampert, E. Mitochondrial Respiratory Chain Function in Skeletal Muscle of ALS Patients. Ann. Neurol. 2002, 52, 623-627. [CrossRef]

91. Krasnianski, A.; Deschauer, M.; Neudecker, S.; Gellerich, F.N.; Müller, T.; Schoser, B.G.; Krasnianski, M.; Zierz, S. Mitochondrial Changes in Skeletal Muscle in Amyotrophic Lateral Sclerosis and Other Neurogenic Atrophies. Brain 2005, 128, 1870-1876. [CrossRef]

92. Ryan, T.E.; Erickson, M.L.; Verma, A.; Chavez, J.; Rivner, M.H.; Mccully, K.K. Skeletal Muscle Oxidative Capacity in Amyotrophic Lateral Sclerosis: Muscle Metabolism in ALS. Muscle Nerve. 2014, 50, 767-774. [CrossRef] [PubMed]

93. Kasarskis, E.J.; Berryman, S.; Vanderleest, J.G.; Schneider, A.R.; McClain, C.J. Nutritional Status of Patients with Amyotrophic Lateral Sclerosis: Relation to the Proximity of Death. Am. J. Clin. Nutr. 1996, 63, 130-137. [CrossRef] 
94. Reyes, E.T.; Perurena, O.H.; Festoff, B.W.; Jorgensen, R.; Moore, W.V. Insulin Resistance in Amyotrophic Lateral Sclerosis. J. Neurol. Sci. 1984, 63, 317-324. [CrossRef]

95. Pradat, P.-F.; Bruneteau, G.; Gordon, P.H.; Dupuis, L.; Bonnefont-Rousselot, D.; Simon, D.; Salachas, F.; Corcia, P.; Frochot, V.; Lacorte, J.-M.; et al. Impaired Glucose Tolerance in Patients with Amyotrophic Lateral Sclerosis. Amyotroph. Lateral Scler. 2010, 11, 166-171. [CrossRef]

96. Desport, J.C.; Preux, P.M.; Truong, T.C.; Vallat, J.M.; Sautereau, D.; Couratier, P. Nutritional Status Is a Prognostic Factor for Survival in ALS Patients. Neurology 1999, 53, 1059. [CrossRef]

97. Marin, B.; Desport, J.C.; Kajeu, P.; Jesus, P.; Nicolaud, B.; Nicol, M.; Preux, P.M.; Couratier, P. Alteration of Nutritional Status at Diagnosis Is a Prognostic Factor for Survival of Amyotrophic Lateral Sclerosis Patients. J. Neurol. Neurosurg. Psychiatry 2011, 82, 628-634. [CrossRef]

98. Nakken, O.; Meyer, H.E.; Stigum, H.; Holmøy, T. High BMI Is Associated with Low ALS Risk: A Population-Based Study. Neurology 2019, 93, e424-e432. [CrossRef]

99. Pape, J.A.; Grose, J.H. The Effects of Diet and Sex in Amyotrophic Lateral Sclerosis. Rev. Neurol. 2020, 176, 301-315. [CrossRef]

100. Jawaid, A.; Murthy, S.B.; Wilson, A.M.; Qureshi, S.U.; Amro, M.J.; Wheaton, M.; Simpson, E.; Harati, Y.; Strutt, A.M.; York, M.K.; et al. A Decrease in Body Mass Index Is Associated with Faster Progression of Motor Symptoms and Shorter Survival in ALS. Amyotroph. Lateral Scler. 2010, 11, 542-548. [CrossRef]

101. Paganoni, S.; Deng, J.; Jaffa, M.; Cudkowicz, M.E.; Wills, A.-M. Body Mass Index, Not Dyslipidemia, Is an Independent Predictor of Survival in Amyotrophic Lateral Sclerosis. Muscle Nerve. 2011, 44, 20-24. [CrossRef] [PubMed]

102. Dardiotis, E.; Siokas, V.; Sokratous, M.; Tsouris, Z.; Aloizou, A.-M.; Florou, D.; Dastamani, M.; Mentis, A.-F.A.; Brotis, A.G. Body Mass Index and Survival from Amyotrophic Lateral Sclerosis: A Meta-Analysis. Neurol. Clin. Pract. 2018, 8, 437-444. [CrossRef] [PubMed]

103. O’Reilly, É.J.; Wang, H.; Weisskopf, M.G.; Fitzgerald, K.C.; Falcone, G.; McCullough, M.L.; Thun, M.; Park, Y.; Kolonel, L.N.; Ascherio, A. Premorbid Body Mass Index and Risk of Amyotrophic Lateral Sclerosis. Amyotroph. Lateral Scler. Front. Degener. 2013, 14, 205-211. [CrossRef] [PubMed]

104. Desport, J.C.; Preux, P.M.; Magy, L.; Boirie, Y.; Vallat, J.M.; Beaufrère, B.; Couratier, P. Factors Correlated with Hypermetabolism in Patients with Amyotrophic Lateral Sclerosis. Am. J. Clin. Nutr. 2001, 74, 328-334. [CrossRef]

105. Desport, J.-C.; Torny, F.; Lacoste, M.; Preux, P.-M.; Couratier, P. Hypermetabolism in ALS: Correlations with Clinical and Paraclinical Parameters. Neurodegener. Dis. 2005, 2, 202-207. [CrossRef]

106. Fayemendy, P.; Marin, B.; Labrunie, A.; Boirie, Y.; Walrand, S.; Achamrah, N.; Coëffier, M.; Preux, P.-M.; Lautrette, G.; Desport, J.-C.; et al. Hypermetabolism Is a Reality in Amyotrophic Lateral Sclerosis Compared to Healthy Subjects. J. Neurol. Sci. 2021, 420, 117257. [CrossRef]

107. Jésus, P.; Fayemendy, P.; Nicol, M.; Lautrette, G.; Sourisseau, H.; Preux, P.-M.; Desport, J.-C.; Marin, B.; Couratier, P. Hypermetabolism Is a Deleterious Prognostic Factor in Patients with Amyotrophic Lateral Sclerosis. Eur. J. Neurol. 2018, 25, 97-104. [CrossRef]

108. Bouteloup, C.; Desport, J.-C.; Clavelou, P.; Guy, N.; Derumeaux-Burel, H.; Ferrier, A.; Couratier, P. Hypermetabolism in ALS Patients: An Early and Persistent Phenomenon. J. Neurol. 2009, 256, 1236-1242. [CrossRef]

109. Steyn, F.J.; Ioannides, Z.A.; van Eijk, R.P.A.; Heggie, S.; Thorpe, K.A.; Ceslis, A.; Heshmat, S.; Henders, A.K.; Wray, N.R.; van den Berg, L.H.; et al. Hypermetabolism in ALS Is Associated with Greater Functional Decline and Shorter Survival. J. Neurol. Neurosurg. Psychiatry 2018, 89, 1016-1023. [CrossRef]

110. Funalot, B.; Desport, J.-C.; Sturtz, F.; Camu, W.; Couratier, P. High Metabolic Level in Patients with Familial Amyotrophic Lateral Sclerosis. Amyotroph. Lateral Scler. 2009, 10, 113-117. [CrossRef]

111. Peter, R.S.; Rosenbohm, A.; Dupuis, L.; Brehme, T.; Kassubek, J.; Rothenbacher, D.; Nagel, G.; Ludolph, A.C. Life Course Body Mass Index and Risk and Prognosis of Amyotrophic Lateral Sclerosis: Results from the ALS Registry Swabia. Eur. J. Epidemiol. 2017, 32, 901-908. [CrossRef]

112. Moglia, C.; Calvo, A.; Grassano, M.; Canosa, A.; Manera, U.; D’Ovidio, F.; Bombaci, A.; Bersano, E.; Mazzini, L.; Mora, G.; et al. Early Weight Loss in Amyotrophic Lateral Sclerosis: Outcome Relevance and Clinical Correlates in a Population-Based Cohort. J. Neurol. Neurosurg. Psychiatry 2019, 90, 666-673. [CrossRef]

113. Dupuis, L.; Corcia, P.; Fergani, A. Dyslipidemia Is a Protective Factor in Amyotrophic Lateral Sclerosis. Neurology 2008, 7, 1004-1009. [CrossRef]

114. Ngo, S.T.; Steyn, F.J.; Huang, L.; Mantovani, S.; Pfluger, C.M.M.; Woodruff, T.M.; O'Sullivan, J.D.; Henderson, R.D.; McCombe, P.A. Altered Expression of Metabolic Proteins and Adipokines in Patients with Amyotrophic Lateral Sclerosis. J. Neurol. Sci. 2015, 357, 22-27. [CrossRef]

115. Dupuis, L.; Oudart, H.; Rene, F.; de Aguilar, J.-L.G.; Loeffler, J.-P. Evidence for Defective Energy Homeostasis in Amyotrophic Lateral Sclerosis: Benefit of a High-Energy Diet in a Transgenic Mouse Model. Proc. Natl. Acad. Sci. USA 2004, 101, 11159-11164. [CrossRef]

116. Palamiuc, L.; Schlagowski, A.; Ngo, S.T.; Vernay, A.; Dirrig-Grosch, S.; Henriques, A.; Boutillier, A.; Zoll, J.; Echaniz-Laguna, A.; Loeffler, J.; et al. A Metabolic Switch toward Lipid Use in Glycolytic Muscle Is an Early Pathologic Event in a Mouse Model of Amyotrophic Lateral Sclerosis. Embo. Mol. Med. 2015, 7, 526-546. [CrossRef] 
117. Joardar, A.; Manzo, E.; Zarnescu, D.C. Metabolic Dysregulation in Amyotrophic Lateral Sclerosis: Challenges and Opportunities. Curr. Genet. Med. Rep. 2017, 5, 108-114. [CrossRef]

118. Jeoung, N.H.; Wu, P.; Joshi, M.A.; Jaskiewicz, J.; Bock, C.B.; Depaoli-Roach, A.A.; Harris, R.A. Role of Pyruvate Dehydrogenase Kinase Isoenzyme 4 (PDHK4) in Glucose Homoeostasis during Starvation. Biochem. J. 2006, 397, 417-425. [CrossRef]

119. Zhang, S.; Hulver, M.W.; McMillan, R.P.; Cline, M.A.; Gilbert, E.R. The Pivotal Role of Pyruvate Dehydrogenase Kinases in Metabolic Flexibility. Nutr. Metab. (Lond.) 2014, 11, 10. [CrossRef]

120. Desseille, C.; Deforges, S.; Biondi, O.; Houdebine, L.; D’amico, D.; Lamazière, A.; Caradeuc, C.; Bertho, G.; Bruneteau, G.; Weill, L.; et al. Specific Physical Exercise Improves Energetic Metabolism in the Skeletal Muscle of Amyotrophic-Lateral- Sclerosis Mice. Front. Mol. Neurosci. 2017, 10, 332. [CrossRef]

121. Telerman-Toppet, N.; Coërs, C. Motor Innervation and Fiber Type Pattern in Amyotrophic Lateral Sclerosis and in Charcot-MarieTooth Disease: Motor Units in ALS and CMT. Muscle Nerve. 1978, 1, 133-139. [CrossRef] [PubMed]

122. Hegedus, J.; Putman, C.T.; Gordon, T. Time Course of Preferential Motor Unit Loss in the SOD1G93A Mouse Model of Amyotrophic Lateral Sclerosis. Neurobiol. Dis. 2007, 28, 154-164. [CrossRef] [PubMed]

123. Hegedus, J.; Putman, C.T.; Tyreman, N.; Gordon, T. Preferential Motor Unit Loss in the SOD1 G93A Transgenic Mouse Model of Amyotrophic Lateral Sclerosis: Motor Units in Mouse ALS. J. Physiol. 2008, 586, 3337-3351. [CrossRef] [PubMed]

124. Atkin, J.D.; Scott, R.L.; West, J.M.; Lopes, E.; Quah, A.K.J.; Cheema, S.S. Properties of Slow- and Fast-Twitch Muscle Fibres in a Mouse Model of Amyotrophic Lateral Sclerosis. Neuromuscul. Disord. 2005, 15, 377-388. [CrossRef] [PubMed]

125. Deforges, S.; Branchu, J.; Biondi, O.; Grondard, C.; Pariset, C.; Lécolle, S.; Lopes, P.; Vidal, P.-P.; Chanoine, C.; Charbonnier, F. Motoneuron Survival Is Promoted by Specific Exercise in a Mouse Model of Amyotrophic Lateral Sclerosis: Motoneuron Activation and Neuroprotection in ALS Mice. J. Physiol. 2009, 587, 3561-3572. [CrossRef] [PubMed]

126. Flis, D.J.; Dzik, K.; Kaczor, J.J.; Cieminski, K.; Halon-Golabek, M.; Antosiewicz, J.; Wieckowski, M.R.; Ziolkowski, W. Swim Training Modulates Mouse Skeletal Muscle Energy Metabolism and Ameliorates Reduction in Grip Strength in a Mouse Model of Amyotrophic Lateral Sclerosis. IJMS 2019, 20, 233. [CrossRef] [PubMed]

127. Randle, P.J.; Garland, P.B.; Hales, C.N.; Newsholme, E.A. The Glucose Fatty-Acid Cycle. Its Role in Insulin Sensitivity and the Metabolic Disturbances of Diabetes Mellitus. Lancet 1963, 1, 785-789. [CrossRef]

128. Bassel-Duby, R.; Olson, E.N. Signaling Pathways in Skeletal Muscle Remodeling. Annu. Rev. Biochem. 2006, 75, 19-37. [CrossRef]

129. Talanian, J.L.; Holloway, G.P.; Snook, L.A.; Heigenhauser, G.J.F.; Bonen, A.; Spriet, L.L. Exercise Training Increases Sarcolemmal and Mitochondrial Fatty Acid Transport Proteins in Human Skeletal Muscle. Endocrinol. Metab. 2010, 299, 9. [CrossRef]

130. Pette, D.; Staron, R.S. Transitions of Muscle Fiber Phenotypic Profiles. Histochem Cell Biol. 2001, 115, 359-372. [CrossRef]

131. Lacorte, E.; Ferrigno, L.; Leoncini, E.; Corbo, M.; Boccia, S.; Vanacore, N. Physical Activity, and Physical Activity Related to Sports, Leisure and Occupational Activity as Risk Factors for ALS: A Systematic Review. Neurosci. Biobehav. Rev. 2016, 66, 61-79. [CrossRef]

132. Bozzoni, V. Amyotrophic Lateral Sclerosis and Environmental Factors. Funct. Neurol. 2016, 31. [CrossRef]

133. Chio, A. Severely Increased Risk of Amyotrophic Lateral Sclerosis among Italian Professional Football Players. Brain 2005, 128, 472-476. [CrossRef]

134. Chio, A.; Mora, G.; Calvo, A.; Mazzini, L.; Bottacchi, E.; Mutani, R. On behalf of the PARALS Epidemiology of ALS in Italy: A 10-Year Prospective Population-Based Study. Neurology 2009, 72, 725-731. [CrossRef]

135. Beghi, E. Are Professional Soccer Players at Higher Risk for ALS? Amyotroph. Lateral Scler. Front. Degener. 2013, 14, 501-506. [CrossRef]

136. Piazza, O.; Sirén, A.-L.; Ehrenreich, H. Soccer, Neurotrauma and Amyotrophic Lateral Sclerosis: Is There a Connection? Curr. Med. Res. Opin. 2004, 20, 505-508. [CrossRef]

137. Al-Chalabi, A.; Hardiman, O. The Epidemiology of ALS: A Conspiracy of Genes, Environment and Time. Nat. Rev. Neurol. 2013, 9, 617-628. [CrossRef]

138. Scarmeas, N.; Shih, T.; Stern, Y.; Ottman, R.; Rowland, L.P. Premorbid Weight, Body Mass, and Varsity Athletics in ALS. Neurology 2002, 59, 773-775. [CrossRef]

139. Huisman, M.H.B.; Seelen, M.; de Jong, S.W.; Dorresteijn, K.R.I.S.; van Doormaal, P.T.C.; van der Kooi, A.J.; de Visser, M.; Schelhaas, H.J.; van den Berg, L.H.; Veldink, J.H. Lifetime Physical Activity and the Risk of Amyotrophic Lateral Sclerosis. J. Neurol. Neurosurg. Psychiatry 2013, 84, 976-981. [CrossRef]

140. Longstreth, W.T.; McGuire, V.; Koepsell, T.D.; Wang, Y.; van Belle, G. Risk of Amyotrophic Lateral Sclerosis and History of Physical Activity: A Population-Based Case-Control Study. Arch Neurol 1998, 55, 201. [CrossRef]

141. Valenti, M.; Pontieri, F.E.; Conti, F.; Altobelli, E.; Manzoni, T.; Frati, L. Amyotrophic Lateral Sclerosis and Sports: A Case-Control Study. Eur. J. Neurol. 2005, 12, 223-225. [CrossRef] [PubMed]

142. Turner, M.R.; Goldacre, R.; Ramagopalan, S.; Talbot, K.; Goldacre, M.J. Autoimmune Disease Preceding Amyotrophic Lateral Sclerosis: An Epidemiologic Study. Neurology 2013, 81, 1222-1225. [CrossRef] [PubMed]

143. Dal Bello-Haas, V.; Florence, J.M. Therapeutic Exercise for People with Amyotrophic Lateral Sclerosis or Motor Neuron Disease. Cochrane Database Syst. Rev. 2013. [CrossRef] [PubMed]

144. Mahoney, D.J.; Rodriguez, C.; Devries, M.; Yasuda, N.; Tarnopolsky, M.A. Effects of High-Intensity Endurance Exercise Training in the G93A Mouse Model of Amyotrophic Lateral Sclerosis. Muscle Nerve. 2004, 29, 656-662. [CrossRef] 
145. Carreras, I.; Yuruker, S.; Aytan, N.; Hossain, L.; Choi, J.-K.; Jenkins, B.G.; Kowall, N.W.; Dedeoglu, A. Moderate Exercise Delays the Motor Performance Decline in a Transgenic Model of ALS. Brain Res. 2010, 1313, 192-201. [CrossRef]

146. Kaspar, B.K.; Frost, L.M.; Christian, L.; Umapathi, P.; Gage, F.H. Synergy of Insulin-like Growth Factor-1 and Exercise in Amyotrophic Lateral Sclerosis. Ann. Neurol. 2005, 57, 649-655. [CrossRef]

147. Grondard, C.; Biondi, O.; Pariset, C.; Lopes, P.; Deforges, S.; Lécolle, S.; Gaspera, B.D.; Gallien, C.-L.; Chanoine, C.; Charbonnier, F. Exercise-Induced Modulation of Calcineurin Activity Parallels the Time Course of Myofibre Transitions. J. Cell. Physiol. 2008, 214, 126-135. [CrossRef]

148. Smittkamp, S.E.; Morris, J.K.; Bomhoff, G.L.; Chertoff, M.E.; Geiger, P.C.; Stanford, J.A. SOD1-G93A Mice Exhibit Muscle-FiberType-Specific Decreases in Glucose Uptake in the Absence of Whole-Body Changes in Metabolism. Neurodegener. Dis. 2013. [CrossRef]

149. Zubiri, I.; Lombardi, V.; Bremang, M.; Mitra, V.; Nardo, G.; Adiutori, R.; Lu, C.-H.; Leoni, E.; Yip, P.; Yildiz, O.; et al. TissueEnhanced Plasma Proteomic Analysis for Disease Stratification in Amyotrophic Lateral Sclerosis. Mol. Neurodegener. 2018, 13, 60. [CrossRef]

150. Ren, J.M.; Marshall, B.A.; Mueckler, M.M.; McCaleb, M.; Amatruda, J.M.; Shulman, G.I. Overexpression of Glut4 Protein in Muscle Increases Basal and Insulin-Stimulated Whole Body Glucose Disposal in Conscious Mice. J. Clin. Investig. 1995, 95, 429-432. [CrossRef]

151. Leturque, A.; Loizeau, M.; Vaulont, S.; Salminen, M.; Girard, J. Improvement of Insulin Action in Diabetic Transgenic Mice Selectively Overexpressing GLUT4 in Skeletal Muscle. Diabetes 1996, 45, 23-27. [CrossRef]

152. Tsao, T.-S.; Burcelin, R.; Katz, E.B.; Huang, L.; Charron, M.J. Enhanced Insulin Action Due to Targeted GLUT4 Overexpression Exclusively in Muscle. Diabetes 1996, 45, 28-36. [CrossRef]

153. Dupuis, L.; Pradat, P.-F.; Ludolph, A.C.; Loeffler, J.-P. Energy Metabolism in Amyotrophic Lateral Sclerosis. Lancet. Neurol. 2011, 10, 75-82. [CrossRef]

154. Saccà, F.; Quarantelli, M.; Rinaldi, C.; Tucci, T.; Piro, R.; Perrotta, G.; Carotenuto, B.; Marsili, A.; Palma, V.; Michele, G.; et al. A Randomized Controlled Clinical Trial of Growth Hormone in Amyotrophic Lateral Sclerosis: Clinical, Neuroimaging, and Hormonal Results. J. Neurol. 2012, 259, 132-138. [CrossRef]

155. Massao Hirabara, S.; de Oliveira Carvalho, C.R.; Mendonça, J.R.; Piltcher Haber, E.; Fernandes, L.C.; Curi, R. Palmitate Acutely Raises Glycogen Synthesis in Rat Soleus Muscle by a Mechanism That Requires Its Metabolization (Randle Cycle). FEBS Lett. 2003, 541, 109-114. [CrossRef]

156. Puigserver, P.; Spiegelman, B.M. Peroxisome Proliferator-Activated Receptor- $\gamma$ Coactivator $1 \alpha$ (PGC-1 $\alpha)$ : Transcriptional Coactivator and Metabolic Regulator. Endocr. Rev. 2003, 24, 78-90. [CrossRef]

157. Thau, N.; Knippenberg, S.; Korner, S.; Rath, K.J.; Dengler, R.; Petri, S. Decreased MRNA Expression of PGC-1> and PGC1>YRegulated Factors in the SOD1G93A ALS Mouse Model and in Human Sporadic ALS. J. Neuropathol. Exp. Neurol. $2012,71,11$. [CrossRef]

158. Cho, Y.; Hazen, B.C.; Russell, A.P.; Kralli, A. Peroxisome Proliferator-Activated Receptor $\gamma$ Coactivator 1 (PGC-1)- and EstrogenRelated Receptor (ERR)-Induced Regulator in Muscle 1 (PERM1) Is a Tissue-Specific Regulator of Oxidative Capacity in Skeletal Muscle Cells. J. Biol. Chem. 2013, 288, 25207-25218. [CrossRef]

159. Cresci, S.; Wright, L.D.; Spratt, J.A.; Briggs, F.N.; Kelly, D.P. Activation of a Novel Metabolic Gene Regulatory Pathway by Chronic Stimulation of Skeletal Muscle. Am. J. Physiol. Cell Physiol. 1996, 270, C1413-C1420. [CrossRef]

160. Gulick, T.; Cresci, S.; Caira, T.; Moore, D.D.; Kelly, D.P. The Peroxisome Proliferator-Activated Receptor Regulates Mitochondrial Fatty Acid Oxidative Enzyme Gene Expression. Proc. Natl. Acad. Sci. USA 1994, 91, 11012-11016. [CrossRef]

161. Finck, B.N.; Bernal-Mizrachi, C.; Han, D.H.; Coleman, T.; Sambandam, N.; LaRiviere, L.L.; Holloszy, J.O.; Semenkovich, C.F.; Kelly, D.P. A Potential Link between Muscle Peroxisome Proliferator- Activated Receptor- $\alpha$ Signaling and Obesity-Related Diabetes. Cell Metab. 2005, 1, 133-144. [CrossRef] [PubMed]

162. Da Cruz, S.; Parone, P.A.; Lopes, V.S.; Lillo, C.; McAlonis-Downes, M.; Lee, S.K.; Vetto, A.P.; Petrosyan, S.; Marsala, M.; Murphy, A.N.; et al. Elevated PGC-1 $\alpha$ Activity Sustains Mitochondrial Biogenesis and Muscle Function without Extending Survival in a Mouse Model of Inherited ALS. Cell Metab. 2012, 15, 778-786. [CrossRef] [PubMed]

163. Lin, J.; Wu, H.; Tarr, P.T.; Zhang, C.-Y.; Wu, Z.; Boss, O.; Michael, L.F.; Puigserver, P.; Isotani, E.; Olson, E.N.; et al. Transcriptional Co-Activator PGC-1 $\alpha$ Drives the Formation of Slow-Twitch Muscle Fibres. Nature 2002, 418, 797-801. [CrossRef] [PubMed]

164. Luquet, S.; Lopez-Soriano, J.; Holst, D.; Fredenrich, A.; Melki, J.; Rassoulzadegan, M.; Grimaldi, P.A. Peroxisome Proliferatoractivated Receptor $\delta$ Controls Muscle Development and Oxydative Capability. FASEB J. 2003, 17, 2299-2301. [CrossRef]

165. Wang, Y.-X.; Zhang, C.-L.; Yu, R.T.; Cho, H.K.; Nelson, M.C.; Bayuga-Ocampo, C.R.; Ham, J.; Kang, H.; Evans, R.M. Regulation of Muscle Fiber Type and Running Endurance by PPARס. PLoS Biol. 2004, 2, e294. [CrossRef]

166. McVeigh, J.J.; Lopaschuk, G.D. Dichloroacetate Stimulation of Glucose Oxidation Improves Recovery of Ischemic Rat Hearts. Am. J. Physiol.-Heart Circ. Physiol. 1990, 259, H1079-H1085. [CrossRef]

167. Whitehouse, S.; Randle, P.J. Activation of Pyruvate Dehydrogenase in Perfused Rat Heart by Dichloroacetate (Short Communication). Biochem. J. 1973, 134, 651-653. [CrossRef]

168. Miquel, E.; Cassina, A.; Martínez-Palma, L.; Bolatto, C.; Trías, E.; Gandelman, M.; Radi, R.; Barbeito, L.; Cassina, P. Modulation of Astrocytic Mitochondrial Function by Dichloroacetate Improves Survival and Motor Performance in Inherited Amyotrophic Lateral Sclerosis. PLoS ONE 2012, 7, e34776. [CrossRef] 
169. DeAngelo, A.B.; George, M.H.; House, D.E. Hepatocarcinogenicity In The Male B6c3f1 Mouse Following A Lifetime Exposure To Dichloroacetic Acid In The Drinking Water: Dose-Response Determination And Modes Of Action. J. Toxicol. Environ. Health 1999, 58, 485-507. [CrossRef]

170. Lionetti, V.; Stanley, W.C.; Recchia, F.A. Modulating Fatty Acid Oxidation in Heart Failure. Cardiovasc. Res. 2011, 90, 202-209. [CrossRef]

171. McCormack, J.G.; Stanley, W.C.; Wolff, A.A. Ranolazine: A Novel Metabolic Modulator for the Treatment of Angina. Gen. Pharmacol. Vasc. Syst. 1998, 30, 639-645. [CrossRef]

172. Tafreshi, M.J.; Fisher, E. Ranolazine: A New Approach to Management of Patients with Angina. Ann. Pharm. 2006, 40, 689-693. [CrossRef]

173. Hill, J.A.; Schofield, R.S. The Use of Ranolazine in Cardiovascular Disease. Expert Opin. Investig. Drugs 2002, 11, 117-123. [CrossRef]

174. Clarke, B. Ranolazine Increases Active Pyruvate Dehydrogenase in Perfused Normoxic Rat Hearts: Evidence for an Indirect Mechanism. J. Mol. Cell. Cardiol. 1996, 28, 341-350. [CrossRef]

175. Stanley, W.C. Partial Fatty Acid Oxidation Inhibitors for Stable Angina. Expert Opin. Investig. Drugs 2002, 11, 615-629. [CrossRef]

176. Mourouzis, I.; Mantzouratou, P.; Galanopoulos, G.; Kostakou, E.; Dhalla, A.K.; Belardinelli, L.; Pantos, C. The Beneficial Effects of Ranolazine on Cardiac Function After Myocardial Infarction Are Greater in Diabetic Than in Nondiabetic Rats. J. Cardiovasc Pharm. 2014, 19, 457-469. [CrossRef]

177. Chaitman, B.R.; Pepine, C.J.; Parker, J.O.; Skopal, J.; Chumakova, G.; Kuch, J.; Wang, W.; Skettino, S.L.; Wolff, A.A. Combination Assessment of Ranolazine In Stable Angina (CARISA) Investigators Effects of Ranolazine with Atenolol, Amlodipine, or Diltiazem on Exercise Tolerance and Angina Frequency in Patients with Severe Chronic Angina: A Randomized Controlled Trial. JAMA 2004, 291, 309-316. [CrossRef]

178. Novak, K.R.; Norman, J.; Mitchell, J.R.; Pinter, M.J.; Rich, M.M. Sodium Channel Slow Inactivation as a Therapeutic Target for Myotonia Congenita. Ann. Neurol. 2015, 77, 320-332. [CrossRef]

179. Fu, Z.; Zhao, L.; Chai, W.; Dong, Z.; Cao, W.; Liu, Z. Ranolazine Recruits Muscle Microvasculature and Enhances Insulin Action in Rats: Ranolazine, Microvasculature and Insulin Action. J. Physiol. 2013, 591, 5235-5249. [CrossRef]

180. Eckel, R.H.; Henry, R.R.; Yue, P.; Dhalla, A.; Wong, P.; Jochelson, P.; Belardinelli, L.; Skyler, J.S. Effect of Ranolazine Monotherapy on Glycemic Control in Subjects With Type 2 Diabetes. Diabetes Care 2015, 38, 1189-1196. [CrossRef]

181. Caminiti, G.; Fossati, C.; Battaglia, D.; Massaro, R.; Rosano, G.; Volterrani, M. Ranolazine Improves Insulin Resistance in Non-Diabetic Patients with Coronary Heart Disease. A Pilot Study. Int. J. Cardiol. 2016, 219, 127-129. [CrossRef] [PubMed]

182. Wolff, A.A.; Rotmensch, H.H.; Stanley, W.C.; Ferrari, R. Metabolic Approaches to the Treatment of Ischemic Heart Disease: The Clinicians' Perspective. Heart Fail. Rev. 2020, 7, 187-203. [CrossRef] [PubMed]

183. Lopaschuk, G.D.; Ussher, J.R.; Folmes, C.D.L.; Jaswal, J.S.; Stanley, W.C. Myocardial Fatty Acid Metabolism in Health and Disease. Physiol. Rev. 2010, 90, 207-258. [CrossRef] [PubMed]

184. Kantor, P.F.; Lucien, A.; Kozak, R.; Lopaschuk, G.D. The Antianginal Drug Trimetazidine Shifts Cardiac Energy Metabolism From Fatty Acid Oxidation to Glucose Oxidation by Inhibiting Mitochondrial Long-Chain 3-Ketoacyl Coenzyme A Thiolase. Circ. Res. 2000, 86, 580-588. [CrossRef]

185. Fang, Y.-H.; Piao, L.; Hong, Z.; Toth, P.T.; Marsboom, G.; Bache-Wiig, P.; Rehman, J.; Archer, S.L. Therapeutic Inhibition of Fatty Acid Oxidation in Right Ventricular Hypertrophy: Exploiting Randle's Cycle. J. Mol. Med. 2012, 90, 31-43. [CrossRef]

186. Ferraro, E.; Pin, F.; Gorini, S.; Pontecorvo, L.; Ferri, A.; Mollace, V.; Costelli, P.; Rosano, G. Improvement of Skeletal Muscle Performance in Ageing by the Metabolic Modulator Trimetazidine: Metabolism Remodeling in Skeletal Muscle. J. CachexiaSarcopenia Muscle 2016, 7, 449-457. [CrossRef]

187. Gatta, L.; Vitiello, L.; Gorini, S.; Chiandotto, S.; Costelli, P.; Giammarioli, A.M.; Malorni, W.; Rosano, G.; Ferraro, E. Modulating the Metabolism by Trimetazidine Enhances Myoblast Differentiation and Promotes Myogenesis in Cachectic Tumor-Bearing C26 Mice. Oncotarget 2017, 8, 113938-113956. [CrossRef]

188. Karahan, G.; Kaya, H.; Erdogan, M.A.; Yigitturk, G.; Gokyayla, E.; Erbas, O. Effects of Trimetazidine on Nerve Regeneration in a Rat Sciatic Nerve Injury Model. Bratisl. Lek. Listy 2019, 120, 777-782. [CrossRef] 